MRS. CAMILLA ANKER-HANSEN (Orcid ID : 0000-0002-7372-9017)

Article type : Review

\title{
The third person in the room: the needs of care partners of older people in home care services. A systematic review from a person-centred perspective.
}

First and corresponding author: Camilla Anker-Hansen, RN, MM, PhD candidate

University College of Southeast Norway, Faculty of Health and Social Sciences, Department of Nursing and Health Sciences, Bakkenteigen, Postbox 235, 3603 Kongsberg, Norway

Telephone: +4744614494

E-mail: Camilla.Anker-hansen@usn.no

2. Kirsti Skovdahl, RN, PhD, Professor

University College of Southeast Norway, Faculty of Health and Social Sciences, Department of Nursing and Health Sciences, Drammen, Postbox 235, 3603 Kongsberg, Norway

Telephone: +4798306108

E-mail: Kirsti.Skovdahl@usn.no

3. Brendan McCormack, DPhil (Oxon.), RGN, RMN, Professor \& Head of the Division of Nursing, Queen Margaret University Edinburgh, Musselburgh, EH21 6UU, UK; Professor II, University College of Southeast Norway, Drammen, Norway, Professor of Nursing, Maribor University, Maribor, Slovenia, Extraordinary Professor, University of Pretoria, Pretoria, South Africa, and Visiting Professor, Ulster University, Ulster

Telephone: +447545 420277

E-mail:BMcCormack@qmu.ac.uk

This article has been accepted for publication and undergone full peer review but has not been through the copyediting, typesetting, pagination and proofreading process, which may lead to differences between this version and the Version of Record. Please cite this article as doi: 10.1111/jocn.14205

This article is protected by copyright. All rights reserved. 
4. Siri Tønnessen, $\mathrm{RN}, \mathrm{PhD}$, associate professor

University College of Southeast Norway, Faculty of Health and Social Sciences, Department of

Nursing and Health Sciences, Bakkenteigen, Postbox 235, 3603 Kongsberg, Norway

Telephone: +4747327454

E-mail: Siri.Tonnessen@usn.no

\section{Funding}

The study was not funded.

\section{Acknowledgments}

The authors wish to warmly thank Jana Myrvold, university librarian at the university college of Southeast Norway for all the help with conducting the searches in this study.

\section{Declaration of Conflicting Interests}

The author(s) declare that they have no conflict of interests.

\section{ABSTRACT}

\section{Aims and objectives}

To identify and synthesise the needs of care partners of older people living at home with assistance from home care services.

\section{Background}

"Aging in place" is a promoted concept where care partners and home care services play significant roles. Identifying the needs of care partners and finding systematic ways of meeting them can help care partners to cope with their role.

\section{Design/ Methods}

This study is based on the PRISMA reporting guidelines. The systematic review of qualitative and quantitative studies was guided by the Joanna Briggs Institute (JBI) methodology.

\section{Results}

In total, 16 studies were included in the review, eleven qualitative and five quantitative. Three main categories were revealed in the analysis; the need for quality interaction, the need for a shared approach to care and the need to feel empowered.

This article is protected by copyright. All rights reserved. 


\section{Conclusion}

Care partners of older people have several, continuously unmet needs. A person-centred perspective can contribute new understandings of how to meet these needs. A knowledge gap has been identified regarding the needs of care partners of older people with mental health problems. There is a need to develop a tool for systematic collaboration between home care services and care partners, so that the identified needs can be met in a more thorough, systematic and person-centred way.

\section{Keywords}

Older people, home health care services, caregivers, family needs, systematic review, collaboration.

\section{Relevance to Clinical Practice}

- The carers in home care services need competence to identify and meet the needs of care partners.

- The implementation of person-centred values in home care services can contribute to meet the needs of care partners to a greater extent than today.

- Future research on the needs of care partners of older people with mental health problems needs to be undertaken.

\section{What does this paper contribute to the wider global clinical community?}

- This article provides a comprehensive review of the literature on the needs of care partners of older people who receive home care services.

- A person-centred approach can help meeting the needs of care partners.

- Future research on the needs of care partners of older people with mental health problems should be undertaken.

\section{INTRODUCTION}

Projections indicate that by 2050 , two out of ten people will be 60 years or older (World Health Organization [WHO] 2016), and the oldest-old will number 434 million (UN 2015). The global shift towards an older population leads to changing health challenges, and there is

This article is protected by copyright. All rights reserved. 
reason to expect shortages of both skilled personnel and voluntary care in the near future (Colombo et al. 2011). In 1994, the health and social policy ministers of the Organisation for Economic Co-operation and Development (OECD) -member countries started to promote the concept of "aging in place" (OECD 1994), and currently the care ground tends to shift towards home-based care (Genet et al. 2012). This shift means that local government agencies face greater responsibilities for health care, and home care services play an increasingly important role as providers of formal care in the home (Tønnessen 2011). Key collaborators for home care services are care partners, who represent significant resources, both for individual care receivers and from an economic perspective. Estimates on the economic value of care partners' contributions vary from country to country, but it is agreed to be significant (Hulme, Carmichael \& Meads 2016). For example, in the USA, $\$ 642$ billion is the estimated cost to replace care partners with skilled paid care (Chari, Engberg, Ray \& Mehrotra 2015). Furthermore, care partners perform tasks that home care services are required to do, but rationalize due to lack of resources (Tønnessen 2016).

Care partners have been called the invisible aid corps because they have neither been recognized, nor focused on (Tønnessen 2011). However, in recent years, care partners have gained a more prominent position in the debate on the present and future caregiving to older people, and the care partners' experience and situation have been widely studied over the last decades (Ott et al. 2007, Pereira et al. 2011, Tuomola et al. 2016). In a systematic review of the support for care partners looking after older persons at home, Stoltz (2004) found that care partners feared social isolation, wanted to socialize with peers and requested respite care for their relatives. However, these results were based on data collected over 14 years ago, and it is unclear if they are still valid today. Social needs were nonetheless identified in a more recent review about patients' and care partners' needs (Keeling 2014). Furthermore, Keeling (2014) emphasized the necessity of information sharing, emotional support and collaboration among the stakeholders (home care services, care partners and care receivers), yet argued that the best way to achieve such collaboration was still unknown. The review (Keeling 2014) addressed all age groups, but the search was restricted to one database (Medline) and studies conducted from 2010 to 2013. In their integrative review, Silva et al. (2013) reported the lack of studies about the needs of care partners of older people living at home. In their findings, four themes were presented; information and training, professional support, effective communication and legal and financial support. Their review (Silva et al. 2013) included studies until 2011 and did not focus on home care services.

This article is protected by copyright. All rights reserved. 
Several studies show that being a care partner can be rewarding and a desired situation, but it can also be burdensome (Cutrino \& Santamaria 2013, Del-Pino-Casado et al. 2014, Liu et al. 2016). The care partner role has been shown to involve a higher prevalence of mental health problems, a higher risk of poverty (Colombo et al. 2011) and a higher degree of poor physical health compared with a non-carer (Berglund et al. 2015). These negative outcomes of caring give cause for concern. If care partners themselves become ill, they can be unable to maintain their care responsibilities. This again can lead to a situation where both the care partner and the service user are in need of healthcare. Thus, the care partners' health can have a significant impact on the total use of healthcare services in a community (Van Houtven \& Norton 2004). Despite extensive research on care partners' needs, none of the mentioned reviews addressed the needs of care partners of older people receiving home care.

Home care services differ widely across the world, but a common denominator is that services are performed at the home of the recipient. Essentially, the services concern healthcare, but also ADL assistance and domestic aid (Genet, Kroneman, Chiatti, Gulácsi \& Boerma 2012). Due to demographic changes there is an increased demand for home care services (Tarricone \& Tsouros 2008). Simultaneously, the number of care partners is growing, and their contribution is crucial for sustainable healthcare (McPherson, Kayes, Moloczij \& Cummins 2014). In order for home care services to provide adequate support for this care partner group, it is essential to gain knowledge about their role and needs and to identify the ways that these findings can be translated into practice.

Person-centred health care has emerged as a strategic focus in health-care policy and in professional practice worldwide (McCormack \& McCance 2017). It is widely used in both research and practice in the nursing field (Dewing 2008, Edvardsson et al. 2008, McCormack \& McCance 2017). Although it is defined in countless ways, McCormack \& McCance's (2017) new definition captures the complex nature of the concept, as follows:

"Person-centredness is an approach to practice established through the formation and fostering of healthful relationships between all care providers, service users and others significant to them in their lives. It is underpinned by values of respect for persons (personhood), individual right to self determination, mutual respect and understanding. It is enabled by cultures of empowerment that foster continuous approaches to practice development" (p. 3).

This definition conveys the complexity of person-centredness, and includes care partners (others significant). Furthermore, the definition is reflected in the authors" "Person-centred Practice Framework" (Fig. 1, McCormack \& McCance 2017, p. 263). The 2017 framework

This article is protected by copyright. All rights reserved. 
has evolved through empirical research over 20 years. The original Person-Centred Nursing (PCN) Framework was developed by McCormack and McCance (2006) and this was derived from previous empirical research focusing on person-centred practice with older people (McCormack 2001) and the experience of caring in nursing (McCance 2001). The Personcentred Practice Framework consists of five domains: 1.) Macro context, 2.) Prerequisites, 3.) Care environment, 4.) Person-centred processes and 5.) Person-centred outcomes (McCormack \& McCance 2017 p.263). The authors argue that the framework is applicable to a range of situations, but emphasize the critical role of strategy and policy frameworks in enabling the development of person-centred practices in organizations and teams (McCormack \& McCance 2017). Relevant constructs from the framework are used in the discussion to enable this present review to be situated in an expanded framework of understanding and to help improve understanding of how care partners' needs can be met.

Figure 1. Person-centred practice Framework re-presented (McCormack \& McCance 2017, p. 264)

In line with this study's person-centred approach, the term "care partner" is consistently used, instead of the more common used term "caregiver". It is argued that the concept of the care partner takes a step away from the traditional paternalistic relationship between the family and the professionals (Eilers 2013), as it implies more of a two-sided relationship between the parties in the care situation.

\section{PURPOSE OF CURRENT STUDY}

Despite the growing body of research concerning care partners, few studies focus on the needs of care partners of older people who receive home care services (Silva et al. 2013). Additionally, there is a lack of studies aiming at finding systematic ways of meeting the identified needs of this care partner group (Keeling 2014). Therefor, this systematic review intends to identify and synthesise the needs of care partners of older people living at home with assistance from home care services, with a focus on their expressed needs. The research question is as follows:

This article is protected by copyright. All rights reserved. 
- What do care partners of older people living at home need from home care services?

This study's purpose is to develop knowledge about the topic and to identify possible approaches to address the expressed needs of the care partners. Furthermore, the study aims to find gaps in the current knowledge status in this area.

\section{METHODS}

Systematic searches were conducted in the following databases; CINAHL Medline, PsycInfo, Embase, SCOPUS, Age Line, Cochrane and SveMed. A two-step search strategy was used, first an electronic search was conducted, and then reference lists from all eligible studies were searched by hand. For search terms/MeSH, see attachment (additional file 1). The search strategy was based on inclusion/exclusion criteria (table 1), which was discussed thoroughly between three of the reviewers (CAH, ST and KS).

\section{Table 1. Inclusion/exclusion criteria}

The year 2000 has been chosen as a starting point for the review because healthcare systems, including home care services, have changed much over the past decades (Genet et al. 2012). Thus, it is reasonable to assume that the care partners' needs may have changed accordingly. Palliative care is excluded, as end-of-life care is a complex specialty (McCallin 2011). Studies across different healthcare systems are included, since this review focuses on care partners' needs, regardless of health policy structures.

\section{Quality assessment of the studies}

Quality assessment was done by using one of JBI critical appraisal instruments depending on the study design: 1.) JBI Critical Appraisal Checklist for Qualitative Research, 2.) JBI Critical Appraisal Checklist for Analytical cross sectional studies, 3.) JBI Critical Appraisal Checklist for Cohort studies. The primary reviewer $(\mathrm{CAH})$ assessed the quality of the quantitative studies together with another reviewer (ST). The same reviewers assessed the qualitative studies individually and then compared the results. There were minimal disagreements; these were discussed until consensus was

This article is protected by copyright. All rights reserved. 
reached. There are no fixed parameters for determining the weight of qualitative studies (Hannes 2011). In this review, all the criteria were given equal value. Studies that met at least $50 \%$ of the maximum score were rated as acceptable in quality (Scholten-Peeters et al. 2003). No studies were excluded due to a low-quality score.

\section{Extracting findings/Analysis}

The qualitative findings were extracted from both the qualitative and quantitative studies and were evaluated to assess the levels of credibility (JBI 2014). There are three levels of credibility, Unequivocal: the findings are beyond reasonable doubt, Credible: the findings are accompanied by an illustration but lacking clear association, Unsupported: the findings are not supported by data (JBI 2014). Six findings were considered US. They were however spread out over the final results/categories and contributed thus not to exclusion of any major finding.

The qualitative findings where analysed and synthesized, using a content analysis supported by Graneheim and Lundman (2004). All the articles were read repeatedly to get a sense of the whole. The extracted text describing care partners' needs formed the unit of analysis, and was divided into meaning units, based on words, sentences or paragraphs which were connected by content and context (Graneheim \& Lundman 2004). Then the meaning units where compressed into shorter sentences, condensed, while still keeping it close to the manifest content. In the next step the condensed meaning units were coded, and codes with similar content were organised into six sub-categories and three categories, still representing the manifest content. In the last step, the categories were seen in the light of the latent content the articles collected represented. Based on this, the categories were compiled into one, overarching theme (Graneheim \& Lundman 2004).

\section{RESULTS}

\section{Figure 2. PRISMA 2009 Flow diagram of selection process.}

The search identified 7528 potentially relevant hits. The studies were screened by title and abstract for eligibility, yelding 116 articles. Since these studies did not provide sufficient information in their titles and abstracts, their full texts were read. Those that failed to meet the inclusion criteria were excluded.

This article is protected by copyright. All rights reserved. 
The final sample consisted of 16 articles, eleven qualitative and five quantitative studies (Fig. 2). A modified version of the JBI QARI data extraction form for interpretive and critical research (JBI 2014) was used for data extractions (Table 2). The main reasons for discarding studies were the care recipient age (median age $<65$ years) or not receiving home care services. The quality assessment of the included studies is presented in Table 3 . Half of the included studies $(n=8)$ were conducted in the Nordic countries. The care partners in the included studies range from immediate family members to friends and neighbours (Table 2). The most common disorders of the care receivers were chronic somatic conditions, such as diabetes, heart and vascular diseases, renal failure and stroke. The number of care partners who participated in the reviewed studies varied from five to 210 care partners, totalling 655 .

\section{Table 2. JBI QARI Data Extraction Form for Interpretive and Critical research}

\section{Table 3. Quality assessment of the included studies}

The analysis revealed the latent theme: "To be seen and treated as a person with own needs", and three interrelated categories: 1.) The need for quality interaction; 2.) The need for a shared approach to care; and 3.) The need to feel empowered (Table 4). The three categories with their sub categories are presented with summaries of relevant findings.

\section{Table 4. Results}

\section{To be seen and treated as a person with own needs}

According to Graneheim and Lundman (2004), the theme in a content analysis can be seen as an underlying meaning through for example the categories, or expression of the latent content of the text. The above-mentioned three categories all represent in different ways the care partners' need to be seen, respected and treated as a person with his or her own needs in the triad of home care servicescare receiver-care partner. Thus, the care partners are in need of a person-centred approach by the home care services to avoid feeling like the third person in the room.

This article is protected by copyright. All rights reserved. 


\section{The need for quality interaction}

The results in this category highlight the importance of quality interaction between the care partners/care receivers and the home care services. It is divided into two subcategories: a) the need for a trustworthy, predictable and flexible service and $b$ ) the need for information and education.

\section{The need for a trustworthy, predictable and flexible service}

A core theme in many of the included studies was the need for a flexible home care service.- (Hegli \& Foss 2009, Leiknes \& Høye 2012, Hautsalo et al. 2013, McCaffrey et al. 2015). The care partners wanted to participate in decisions relating to how the service would be provided; particularly, the question of when it would be provided and by whom was raised in several studies (Sooden et al. 2007, Hegli \& Foss 2009, Sims-Gould \& Martin-Matthews 2010, Leiknes \& Høye 2012, Hautsalo et al. 2013, Landmark et al. 2013). Having many different care workers was experienced as a burden (Sooden et al. 2007, Landmark et al. 2013), and it was argued that a few, familiar care workers was the optimal solution to ensure a sense of security and continuity of care (Efraimsson 2001, SimsGould \& Martin-Matthews 2010, Hautsalo et al. 2013). However, Gjevjon et al. (2016) found that a high number of care workers might be acceptable, as long as they were well informed about the service they should provide.

\section{The need for information and education}

A longitudinal study's (Armstrong-Esther et al. 2005) results showed that in terms of training and education, the area of greatest need was how to manage the care partners' own stress and health. They also requested training in basic nursing and information about dementia and stroke. Similar findings were reported by five other studies (Ploeg et al. 2001, Wilkins 2009, Saunders 2012, Landmark et al. 2013, McCormack \& Skatvedt 2016). The key message in these studies was that the care partners needed knowledge about their care receivers' diseases, as well as practical skills to take care of themselves.

Other studies reported on the need for more information exchange between families and home care services (Hautsalo et al. 2013, McCaffrey et al. 2015) and for municipalities to develop systems of engagement, education and information sources (McCormack \& Skatvedt 2016). These requirements resonated with Ploeg et al.'s (2001) findings, that the most common needs among the care partners were to have a social life and instrumental, informational-and emotional support. Additionally, care

This article is protected by copyright. All rights reserved. 
partners required more information at the organizational level, specifically, how to navigate the municipal health care services and obtain facts about what services were available for them. The study (Ploeg et al. 2001) also indicated that some of the informational needs might be met through a telephone support service. Some of these findings were supported by McCaffrey et al.'s (2015) study, whose participants repeatedly raised the issue with timely, available information about home care service. Hautsalo et al. (2013) in turn requested a greater degree of information exchange between families and carers. Finally, Van Houtven et al. (2010) found that the majority of the care partners were interested in participating in a care partner training program. However, it was argued (Van Houtven et al. 2010) that care partner training should be tailored to cover different care partner conditions, interests and barriers to participation.

To conclude this section, the studies identified the need for services characterized by trust, flexibility and continuity. Furthermore, the care partners expressed their need for additional knowledge about both the care receivers' diseases and their own situations as the main care partners. They also wanted more information exchange with the home care services, and help to navigate in the municipal health care services.

\section{The need for a shared approach to care}

The studies in this category reported on how care partners felt weighed down by their responsibilities as primary care partners and how they perceived their urgent need for respite, a social life and someone with whom to share the responsibilities. This category is also separated into two subcategories: a) the need for personal space and b) the need for sharing responsibility.

\section{The need for personal space}

Sooden et al. (2007) found two major themes in their study; relief and continuity. The results showed that a few minutes alone to read the newspaper or take a walk to the bank or to the store were "stolen moments" that helped rejuvenate the care partners. This fact was echoed in several studies in this review. In a qualitative study (Wester et al. 2013), the care partners reported that they wanted time off from the care receivers to be able to pursue their own interests. Furthermore, Saunders (2012) found that respite was regarded as the most important care partner need, and the study by Landmark et al. (2013) highlighted that home care must assess such need. In the latter study, all of the care partners experienced a common feeling, described as "being stuck in it and unable to leave" (Landmark et al. 2013, p.219), which reflected a general sentiment across the studies reporting on this subcategory

This article is protected by copyright. All rights reserved. 
(Ploeg et al. 2001, Sooden et al. 2007, Leiknes \& Høye 2012, Saunders 2012, Wester et al. 2013). One exception was a study (Armstrong-Esther et al. 2005), where the majority of the care partners acknowledged having enough time away from caregiving. Finally, Efraimsson et al. (2001)-found that care partners experienced having to give up their privacy, due to the necessity of opening their homes to professional carers.

\section{The need for sharing responsibility}

Hegli and Foss (2009) found that care partners showed signs of an exhausting and isolated existence where they received little support. They wanted to participate in partnership with home care services, but did not know how. Similarly, Efraimsson et al. (2001) noted that care partners were sometimes weighed down by the burden of care. The care partners also mentioned the strain of opening their homes to the home care services. According to McCormack and Skatvedt (2016), care partners and older people needed high levels of energy to express their needs and have them fulfilled. On the contrary, for others, receiving home care services meant an opportunity to share the caregiving responsibilities (Sooden et al. 2007, Leiknes \& Høye 2012).

Hautsalo et al. (2013) pointed out that collaboration among the different stakeholders in home care services was crucial, and care workers emphasized that care partners' ability to contribute to the caregiving process should also be identified. This perspective was to a certain extent shared by Landmark et al. (2013), who argued that care partners must be included in the assessments undertaken by home care services, but the focus should be to identify the care partners' own needs. Based on these individual needs, personalised assistance should be offered and through this, help alleviate care partners' burden and powerlessness.

This category shows care partners' need for personal time and space, and the request for relief is a recurring theme. Many of the care partners want to share the responsibility for care. The importance of collaboration among the different stakeholders in home care services is addressed, and how care partners' own needs must be identified.

\section{The need to feel empowered}

This last category identifies the care partners' need for support and emotional connection. The need for support at different levels was reflected in several studies. The sub categories have thus been designated as: a) the need for a supportive space and b) the need for emotional connection.

This article is protected by copyright. All rights reserved. 
The need for a supportive space.

McCormack and Skatvedt (2016) found that care partners expressed their need to be seen, respected and acknowledged, but the authors described a reality that was far from this wish. Their study highlighted how care partners and older people appeared voiceless in a system that was difficult to navigate, and in the end, they did not experience care as being person-centred. Landmark et al. (2013) also focused on the person-centred perspective, stating that person-centred care should be facilitated by home care services. Their results revealed that home care services did not seek the care partners' experience. Furthermore, Landmark et al. (2013) emphasized the necessity for home care services to consider the needs of care partners as well, in order to prevent health problems and stress.

When care partners talked about what kind of assistance they wanted from home care services, they mostly desired help for their relatives, not for themselves (Sims-Gould \& Martin-Matthews 2010, Saunders 2012). They worried about the care receivers' helplessness, whether they had satisfactory social contact and the way they were being treated by the carers in home care services (Landmark et al. 2013). Sooden et al. (2007) found that care partners received indirect support when home care services helped allay their concerns for their spouses. In Ploeg et al.'s study (2001), the care partners said quite simply that they wanted more hours of support.

\section{The need for emotional connection.}

In their study, Sooden et al. (2007) revealed the care partners' need for an emotional component in their relationship with the home care services. Furthermore, they pointed out that the emotional connection required a stable and on-going relationship among the care triad of home care servicescare partners -care receivers. One of their conclusions was that home care services involved more than service delivery; it was about relationships. This was confirmed by Sims-Gould and MartinMatthews' (2010) findings, where the importance of affective assistance was stressed. As reported by Landmark et al. (2013), this was first and foremost a concern on behalf of the care receiver, but also embraces them in a wider context. The results showed a satisfying relationship between the care receiver and home care services as a prerequisite for the successful collaboration between the care partner and the home care staff.

This article is protected by copyright. All rights reserved. 
In Ploeg et al.'s (2001) study, some care partners expressed their need for emotional support. One care partner talked about the importance of having emotional support when he first entered the role as care partner and elaborated, "when it hits, it really hits you" (Ploeg et al. 2001, p. 54). Finally, Efraimsson et al. (2001) and Leiknes and Høye (2012) concluded with statements that care partners' access to emotional support must be addressed.

In summary, the findings in this category showed that care partners wanted to be seen, respected and acknowledged, and they wished for more hours of support. More home care support for the persons they cared for could also be experienced as help for the care partners. Finally, their need for emotional support was expressed.

\section{DISCUSSION}

The research question in this systematic review is "What do care partners of older people living at home need from home care services?". The results indicate that care partners have several continuously unmet needs. Briefly summarized, care partners want a trustworthy service that adapts to their needs, desire more information and training, and need relief and support. These demands are echoed in the broader research literature about care partners' needs, which seem to be stable over time (Barnes et al. 1992, Soothill et al._2003, Shanley et al. 2011). The majority of the included studies in this review stem from the present decade, and they all point in the same direction; care partners continue to have several unmet needs despite the growing body of knowledge about their requirements. In the past, care partners have been characterized as "an appendage to the patient", and not as a person in his or her own right (Spackman 1991). This is also reflected in the title of this review, "the third person in the room", directed by the expression the "third wheel", indicating a person who feels left out or ignored by the others in a situation. The latent theme summarizes these observations, where the underlying meaning throughout the included studies is identified as the care partners' need to be seen and treated as persons with their own requirements.

The situation of care partners is thus well known, well described and well documented. However, this is not the case in the context of care partners of older people with mental health problems, as identified in this systematic review. Out of the 7528 initially identified studies, only one investigated this care partner group (McCormack \& Skatvedt 2016). This review has thus identified a gap in the current knowledge about care partners' needs from home care services. The results of McCormack and Skatvedt's (2016) study did not differ significantly from those of the other studies in this review.

This article is protected by copyright. All rights reserved. 
It would nevertheless be interesting to explore in depth the needs of care partners of older people with mental health problems to determine if they have similar or other needs than those of care partners of older people with somatic illnesses.

Recommendations are set out in guidelines, official documents and regulations for a greater emphasis on the needs of care partners (Legislation.vic.gov.au 2012, Legislation.gov.uk 2014). Nonetheless, the home care services fail to meet all of these needs. McCormack and Skatvedt (2016) found that there is an apparent lack of acknowledgement, recognition and respect in the services provided to older people and their care partners. It can be argued that the failure over decades in meeting care partners' needs can partly stem from a common health care driven philosophy of 'one size fits all' (Buetow 2016). Although person-centred health care is on the global political agenda (WHO 2007), it is contended that the modern health care system cannot resist the movement towards standardization (Buetow 2016). This viewpoint resonated in several of the included studies, which emphasized the importance of a person-centred approach directly (Landmark et al. 2013, McCormack \& Skatvedt 2016), or indirectly (Hegli and Foss 2009, Van Houtven et al. 2010), but the care was not experienced as person-centred.

Home care services need a way to respond to the recognized challenges. Identifying new alternative solutions to complicated, persistent issues requires complex strategies. As stated, the person-centred perspective offers a multifaceted approach to practice. However, it would be a simplification to believe that using a person-centred thinking for the work with care partners is a "quick fix". Implementing a person-centred approach in an organization is a complex and demanding job that requires long-term work and focus (McCormack \& McCance 2017). However, it is reasonable to assume that by adapting this approach, care partners can have their needs met to a much greater extent than what is accomplished today. The new version of the Person-centred Practice Framework (McCormack \& McCance 2017) includes constructs at both micro and macro levels, which aim at person-centred outcomes. This model focuses on person-centredness as a cultural construct, that is, service-users/patients can only experience person-centred care if all other aspects of the care setting/organization are also person-centred. Person-centredness applies to all persons, and the various factors that influence the existence of such a culture should be addressed. Thus, it is reasonable to apply these same person-centred principles to care partners, as will be demonstrated here.

This article is protected by copyright. All rights reserved. 
All the identified needs in this article can be elaborated in relation to several components of the framework. However, in this context, the goal is to find out how the framework can shed new light on the research question, not to provide an exhaustive overview of the framework. It is nonetheless noteworthy that the constructs described here are part of a whole, where specific relationships exist between the main domains, the constructs and attributes (McCormack \& McCance 2017). In the next section, this study's findings are seen in the light of the relevant constructs of the framework (Fig. 1).

\section{Macro Context}

The macro context consists of four components (Fig. 1, McCormack \& McCance 2017) in which the health and social care policy is sets the agenda for the extent to which the carers are able to meet many of the needs discovered in this study. With the introduction of new public management, especially in the western countries in the early eighties, the focus became the economic efficiency of the public sector, using management principles from the private sector (Klijn 2012). In healthcare systems that are supplied through taxations, the finances available together with the health policy have an impact on which areas of health are being prioritized and on what care is actually provided. Thus, the financial framework largely controls the conditions for service delivery by home care to both service users and their care partners. An overall emphasis on efficiency puts restrictions on the standard for the service provided in each home care district. The consequences of such fiscal priorities are inconsistencies in service provision (Tønnessen 2011). With a working day characterized by time constraints, staff shortage and unforeseen events, it can be difficult to be flexible, informative and emotionally supportive for the carers in home care. Due to the lack of financial resources to provide all services that citizens are entitled to, they are forced to prioritize. The way care partners repeatedly express their needs without having them met, as identified in this review, can be linked with these capacity problems in the municipalities. There are not enough resources to take care of both care partners' and service users' requirements, which can lead to the care partners' needs being rationalized. Furthermore, limited budgets place limitations on the respite services the that a municipality can offer, both day care and short term stays in nursing homes.

Thus, the macro level mechanisms in the person-centred framework in many ways set the agenda for the services provided by home care. According to McCormack and McCance (2017), the absence of supportive policies and strategic directions will "...feel at best like swimming against the tide, or at worst drowning in a sea of competing and changing priorities" (p. 262). The macro level is thus an important backdrop for discussing other aspects of person-centredness in the context of care partners.

This article is protected by copyright. All rights reserved. 


\section{Prerequisites}

Prerequisites focus on the attributes of staff. The attributes are considered key elements to enable the formal carers to deliver effective person-centred care (Fig. 1, McCormack \& McCance 2017), and can be considered prerequisites for meeting the identified needs of care partners in this review. Being Professionally competent is seen in a holistic way, which includes knowledge, skills and attitudes. A core challenge in meeting care partners and their needs, is that they are often invisible. The formal carers need expertise to see care partners as persons with needs and to be able to identify their specific requirements (Tønnessen 2011). The person-centred framework is a value-based one, which also reflects how competence is viewed; as shaped by values in the workplace. To focus on care partners and their needs, this competence must be incorporated as an important value to develop expertise in this area within the organization.

The need for information and education was identified in several of the included studies (Efraimsson et al. 2001, Ploeg et al. 2001, Armstrong-Esther et al. 2005, Wilkins et al. 2009, Van Houtven et al. 2010, Saunders 2012, Hautsalo et al. 2013, Landmark et al. 2013, McCaffrey et al. 2015, McCormack $\&$ Skatvedt 2016). For instance, McCaffrey et al. (2015) highlighted the challenge of choosing among different service possibilities without adequate information. It is reasonable to assume that with a more holistic approach to competence, the formal carers will be in a better position to capture these needs of the care partners, as well as take action to meet them. On the other hand, knowledge and skills alone will not automatically lead to changes. This is reflected in the construct Developed interpersonal skills. Being a warm and friendly practitioner is not enough to make an effective impact; there is a need to step into the world of the other person and engage profoundly in courageous conversations (McCormack \& McCance 2017). In this context, "the other person" is the care partner. The first step in meeting their needs, is for the home care staff to be aware of the existence of those needs. In one of the included studies (Hegli \& Foss 2009), some of the care partners wanted to be involved in decision-making processes. However, they did not express their wish to the home care staff. This was explained in various ways, including the care partners' respect for health professionals as authorities, with the right to make decisions (Hegli \& Foss 2009). This illustrates an issue that could have been solved if the home care staff were trained to provide a space for care partners, were they could identify and express their own needs. According to the framework, the formal carers need to develop advanced communication skills in order to capture what is of real importance to the individual person (McCormack \& McCance 2017). The adaption of these skills can be of help to start recognising the individual care partner and his or her unique needs, both those that are easy to articulate and those that are more difficult.

This article is protected by copyright. All rights reserved. 


\section{Care Environment}

The context of care delivery by home care services is multifaceted. There are complex prioritization and decision-making processes, both within the organization and for the individual formal carer (Tønnessen 2011). The work environment consists of both permanent offices where the services are administered and several homes where the home care staff meet service users/care partners with different expectations and needs. The Person-centred Practice Framework places great emphasis on the care environment, which focuses on the context of the care delivery (McCormack \& McCance 2017). One of the characteristics to be found here is the sharing of power, which confronts the typical hierarchical structure of many health authorities. This hierarchical structure may have an impact on how a trustworthy, predictable and flexible service is achieved. One of the included studies (Leiknes \& Høye 2012) pointed out the service's flexibility, but only to suit the needs of the home care services. Home care staff could for instance call to cancel a visit, whereas the care partners would have to apply for any changes in the schedule several days in advance. By implementing values of shared power in the home care services, the emphasis should be on the best possible results for all parties involved based on agreed values, goals and wishes (McCormack \& McCance 2017), -not only on the most advantageous outcome for one party. Doing so may also involve a higher degree of trustworthiness and a predictable service.

\section{Person-centred processes}

Person-centred processes focus on care delivery through activities that operationalize person-centred practices (McCormack \& McCance 2017). The need for personal space can be facilitated through the construct sharing decision-making within person-centred processes. As stated, several care partners requested personal time and space (Ploeg et al. 2001, Sooden et al. 2007, Saunders 2012, Wester et al. 2013). Respite care was mentioned, both in-house (Ploeg et al. 2007) and in nursing homes (Leiknes \& Høye 2012). Though offering the care partners the possibility to have a voice in the decisionmaking processes about how and where respite can be offered, they are more likely to achieve the form of personal space/ respite that they need. However, some of the care receivers only reluctantly accepted respite care, and the issue of needing personal time also led to feelings of guilt for their care partners (Leiknes \& Høye 2012).

Taking part of a shared decision-making process can also prevent the occurrence of unwanted incidents. A care partner reported about a cut in the hours of service from home care, resulting in a service that was no longer satisfactory (Ploeg et al. 2001). This could have been avoided if the care partner and/or service user had been given the power to actually influence the decision-making

This article is protected by copyright. All rights reserved. 
process. In another study (Saunders 2012), the care partners stated that by improving the care receivers' functions, they got more free time. If care partners are given the opportunity to communicate own solutions to their needs in dialogues with staff in home care services, new, satisfactory solutions can be found.

\section{Person-centred outcomes}

The person-centred outcomes represent the expected results of working with the other constructs in the framework. The outcomes are as follows: good care experience, involvement in care, feeling of well-being and the existence of a healthy culture (McCormack \& McCance 2017, pp. 58-59). It is reasonable to assume that by achieving those outcomes, most of the needs described by the care partners in this study will be met. However, future research should consider the best way to evaluate the attainment of these outcomes from care partners' perspectives.

\section{CONCLUSION}

This review has identified knowledge about the needs of care partners of older people who receive home care services. The needs continuum ranges from practical help to emotional support. Studies in this area are limited, particularly those about care partners to of older people with mental health problems. The discussion of the findings has highlighted the benefits of using the Person-centred Practice Framework to help meet the care partners' needs. This study's findings have both policy and organizational implications. Developing a person-centred culture in service organizations, where care partners constitute an integral part of holistic thinking about care practice, increases the possibility of fulfilling care partners' needs. The development of a person-centred organizational culture is a complex matter, which must be rooted at all levels, from the micro to the macro level. Based on these findings, this review proposes that a model for systematic collaboration between care partners and home care services should be developed, founded on the principles of person-centred health care

\section{Strengths and limitations}

Several limitations are noted to this study. The search was restricted to English and Scandinavian language, and in time, from 2000-2016. Due to these restrictions, publications may have been missed. The analysis and extractions of data/finding was done by only one reviewer $(\mathrm{CAH})$, but the findings were discussed continuously with another reviewer (ST). Furthermore, methodological considerations

This article is protected by copyright. All rights reserved. 
may have been inadequately investigated when synthesising the findings from the qualitative and quantitative studies. And finally, a protocol for the review was not registered.

Although the study has methodological issues and limitations, it has several strengths. The primary strength is that this is one of the first systematic reviews to identify a gap in the current knowledge about what care partners of older people with mental health problems living at home need from home care services. Furthermore, the systematic search yielded a rich amount of hits, and the review has been completed in a systematic and rigorous manner.

\section{Acknowledgments}

The authors wish to warmly thank Jana Myrvold, university librarian at the university college of Southeast Norway for all the help with conducting the searches in this study.

\section{Declaration of Conflicting Interests}

The author(s) declare that they have no conflict of interests.

\section{REFERENCES}

Armstrong-Esther C, Hagen B, Sandilands M, Williams R \& Smith C (2005) A longitudinal study of home care clients and their informal carers. British Journal of Community Nursing 10, 284-291.

Barnes ClL, Given BA \& Given CW (1992) Caregivers of elderly relatives: spouses and adult children. Health and social work 17, 282-289.

Berglund E, Lutsy P \& Westerling R (2015) Health and wellbeing in informal caregivers and noncaregivers: a comparative cross-sectional study of the Swedish general population. Health and Quality of Life Outcomes 13, 1-11.

Buetow S. (2016) Person-centred health care: Balancing the welfare of clinicians and patients. Routledge, Abingdon, Oxon, New York.

This article is protected by copyright. All rights reserved. 
Chari AV, Engberg J, Ray, KN \& Mehrotra A (2015) The Opportunity Costs of Informal Elder-Care in the United States: New Estimates from the American Time Use Survey. Health Serv Res, 50: 871882. doi:10.1111/1475-6773.12238

Colombo F et al. (2011) Help wanted? Providing and paying for long-term care. OECD health policy studies, OECD Publishing. http://dx.doi.org/10.1787/9789264097759-en

Cutrino A \& Santamaria J (2013) Research on family caregivers: understanding levels of burden and how to provide assistance. Home healthcare nurse 31, 331-337.

Del-Pino-Casado R, Pérez-Cruz M \& Frías-Osuna A (2014) Coping, subjective burden and anxiety among family caregivers of older dependents. Journal of Clinical Nursing 23, 3335-3344

Dewing J (2008) Personhood and dementia: revisiting Tom Kitwood's ideas. International Journal of older people nursing $\mathbf{3}, 3-13$.

Edvardsson D, Winblad B \& Sandman P-O (2008) "Person-centred care of people with severe Alzheimer's disease: current status and ways forward." The Lancet Neurology 7, 362-367.

Efraimsson E, Höglund I \& Sandman PO (2001) 'The everlasting trial of strength and patience': transitions in home care nursing as narrated by patients and family members. Journal of Clinical Nursing 10, 813-819.

Eilers D (2013) What's in a word -Caregiver or care partner? Nephrology Nursing Journal 40, 61-62.

Genet N, Boerma W, Kroneman M, Hutchinson A \& Saltman RB (ed) (2012)

Home Care across Europe. Current structure and future challenges. European Observatory on health systems and policies, Copenhagen.

Genet N, Kroneman M, Chiatti C, Gulácsi L \& Boerma W (2012) The policy perspective. In: Genet N, Boerma W, Kroneman M, Hutchinson A \& Saltman RB (ed.) Home Care across Europe. Current structure and future challenges. European Observatory on health systems and policies, Copenhagen.

This article is protected by copyright. All rights reserved. 
Gjevjon ER, Romøren TI, Bragstad LK \& Hellesø R (2016) Older patients' and next of kin's perspectives on continuity in long-term home health care. Home Health Care Management \& Practice 28, 142-149.

Graneheim UH \& Lundman B (2004) Qualitative content analysis in nursing research: concepts, procedures and measures to achieve trustworthiness. Nurse Education Today 24, 105-112.

Hannes K (2011) Critical appraisal of qualitative research. In: Noyes J, Booth A, Hannes K, Harden A, Harris J, Lewin S \& Lockwood C (ed), Supplementary Guidance for Inclusion of Qualitative Research in Cochrane Systematic Reviews of Interventions. Cochrane Collaboration Qualitative Methods Group. Available at: http://cqrmg.cochrane.org/supplemental-handbook-guidance [Accessed 10. Aug. 2016].

Hautsalo K, Rantanen A \& Astedt-Kurki P (2013) Family functioning, health and social support assessed by aged home care clients and their family members. Journal of Clinical Nursing 22, 29532963.

Hegli T \& Foss C (2009) The "lost" negotiations - Participation in the decision-making process with the home nursing care, as experienced by elderly spousal caregivers. [De "tapte" forhandlinger - Eldre ektefellers erfaringer med medvirkning i mötet med hjemmesykepleien]. Vård i Norden 29, 23-27.

Hulme C, Carmichael F \& Meads D (2016) What about informal carers and families. In Round, J (ed) Care at the end of life. An economic perspective. Heidelberg: Springer.

The Joanna Briggs Institute. (2014) Joanna Briggs Institute Reviewers' Manual: 2014 edition. Adelaide: The Joanna Briggs Institute.

Keeling DI (2014) Homecare user needs from the perspective of the patient and carers: a review. Smart homecare technology and telehealth 2, 63-76.

Klijn EH (2012) New public management and governance: a comparison. In The Oxford Handbook of Governance. (Levi-Fauver D ed.), Oxford University Press Inc., New York, pp. 201-214.

This article is protected by copyright. All rights reserved. 
Landmark BT, Aasgaard HS \& Fagerström L (2013) "To be stuck in it—I Can't Just Leave": A Qualitative Study of Relatives' Experiences of Dementia Suffers Living at Home and Need for Support. Home Health Care Management \& Practice 25, 217-223.

Legislation.vic.gov.au (2012) Carers recognition Act 2012. [Online] Available at: http://www.legislation.vic.gov.au [Accessed 5. Jan. 2017].

Legislation.gov.uk. (2014) Care Act 2014. [Online] Available at: http://www.legislation.gov.uk/ukpga/2014/23/contents/enacted [Accessed 5. January 2017].

Leiknes I \& Høye S (2012) Family caregivers experiences of provided home care to persons with Parkinson's disease. Nordisk Sygeplejeforskning 2, 29-44.

Liu S, Li C, Shi Z, Wang X, Zhou Y, Liu S, Liu J, Yu T\& Ji Y (2016) Caregiver burden and prevalence of depression, anxiety and sleep disturbances in Alzheimer's disease caregivers in China. Journal of Clinical Nursing. doi:10.1111/jocn.13601

McCaffrey N, Gill L, Kaambwa B, Cameron ID, Patterson J, Crotty M \& Ratcliffe J (2015) Important features of home-based support services for older Australians and their informal carers. Health \& Social Care in the Community 23, 654-664.

McCallin AM (2011) Moderated guiding: a grounded theory of nursing practice in end-of-life care. Journal of clinical nursing 20, 2325-33.

McCance TV, McKenna HP, Boore JRP (2001) Exploring caring using narrative methodology: an analysis of the approach. Journal of Advanced Nursing 33, 350-6.

McCormack B \& McCance T (ed.). (2017) Person-Centred practice in nursing and health care. Theory and practice. Wiley Blackwell, West Sussex, UK

McCormack B \& Skatvedt A (2016) Older people and their care partners' experiences of living with mental health needs: A focus on collaboration and cooperation. Journal of Clinical Nursing 26, 103114.

This article is protected by copyright. All rights reserved. 
McCormack B and McCance T (2006) Development of a framework for person-centred nursing. Journal of Advanced Nursing 56, 1-8.

McCormack B (2001) Autonomy and the relationship between nurses and older people. Ageing and Society 21, 417-46.

McPherson KM, Kayes NK1, Moloczij N \& Cummins (2014 ) Improving the interface between informal carers and formal health and social services: A qualitative study. International Journal of Nursing Studies 51, 418-429.

Moher D, Liberati A, Tetzlaff J, Altman DG, The PRISMA Group (2009) Preferred Reporting Items for Systematic Reviews and Meta-Analyses: The PRISMA Statement. PLoS Med 6(7): e1000097. doi:10.1371/journal.pmed1000097

OECD (1994) Caring for Frail Elderly People: New Directions in Care, Organisation for Economic Co-operation and Development, Paris.

Ott CH, Sanders S, \& Kelber ST (2007) Grief and personal growth experience of spouses and adultchild caregivers of individuals with Alzheimer's disease and related dementias. The Gerontologist 47, 798-809.

Pereira HR, Botelho R \& Antónia M (2011) Sudden informal caregivers: the lived experience of informal caregivers after an unexpected event. Journal of Clinical Nursing 20, 2448-2457.

Ploeg J, Biehler L, Willison K, Hutchison B, \& Blythe J (2001) Perceived support needs of family caregivers and implications for a telephone support service. Canadian Journal of Nursing Research 33, 43-61.

Saunders MM (2012) Perspectives From Family Caregivers Receiving Home Nursing Support: Findings from a qualitative study of home care patients with heart failure. Home Healthcare Nurse 30, 82-90.

Scholten-Peeters GG, Verhagen AP, Bekkering GE, van der Windt DA, Barnsley L, Oostendorp RA \& Hendriks EJ (2003) Prognostic factors of whiplash-associated disorders: a systematic review of prospective cohort studies. Pain 104, 303-322.

This article is protected by copyright. All rights reserved. 
Shanley C, Russell C, Middleton H \& Simpson-Young V (2011) Living through end-stage dementia: the experiences and expressed needs of family carers. Dementia 10, 325-340.

Silva AL, Teixeira HJ, Teixeira MJC \& Freitas S (2013) The needs of informal caregivers of elderly people living at home: an integrative review. Scandinavian Journal of Caring Sciences 27, 792-803.

Sims-Gould J \& Martin-Matthews A (2010) We share the care: family caregivers' experiences of their older relative receiving home support services. Health \& Social Care in the Community 18, 415-423.

Soodeen RA, Gregory D \& Bond Jr J (2007). Home care for older couples: "It feels like a security blanket..." Qualitative Health Research 17, 1245-1255.

Soothill K, Morris SM, Thomas C, Harman JC, Francis B \& Mclllmurray (2003) The universal, situational, and personal needs of cancer patients and their main carers. European journal of oncology nursing 7, 5-11.

Tarricone R \& Tsouros AD (2008) Home care in Europe. World Health Organisation

Tuomola J, Soon J, Fisher P \& Yap P (2016) Lived experience of caregivers of persons with dementia and the impact on their sense of self: a qualitative study in Singapore. Journal of Cross-Cultural Gerontology 31, 157-172.

Tønnessen S (2011) The Challenge to Provide Sound and Diligent Care. A qualitative study of nurses' decisions about prioritization and patients' experiences of the home nursing service. University of Oslo, Oslo, Norway.

Tønnessen S (2016) Pårørende: Usynlige barebjelker i velferdsstaten. I Vike H, Debesay J \& Haukelien H (2016) (ed) Tilbakeblikk på velferdsstaten. Politikk, styring og tjenester. Gyldendal Akademisk.

United Nations, Department of Economic and Social Affairs, Population Division (2015) World Population Ageing 2015 (ST/ESA/SER.A/390).

Van Houtven CH, Oddone EZ \& Weinberger M (2010) Informal and formal care infrastructure and

This article is protected by copyright. All rights reserved. 
perceived need for caregiver training for frail US veterans referred to home and community-based services. Chronic Illness 6, 57-66.

Van Houtven CH \& Norton EC (2004) Informal care and health care use of older adults. Journal of Health Economics 23, 1159-1180.

Ward-Griffin C \& Marshall VW (2003) Reconceptualizing the relationship between "public" and "private" eldercare. Journal Of Aging Studies 17, 189-208.

Wester A, Larsson L, Olofsson L \& Pennbrant S (2013) Caregivers' experiences of caring for an elderly next of kin in Sweden. Vård i Norden 33, 28-32.

Wilkins VM, Bruce ML \& Sirey JA (2009) Caregiving tasks and training interest of family caregivers of medically ill homebound older adults. Journal of Aging \& Health 21, 528-542.

World Health Organisation (2016) Global strategy and action plan on ageing and health (20162020). A framework for coordinated global action by the World Health Organization, Member States, and Partners across the Sustainable Development Goals. From http://www.who.int/ageing/GSAPSummary-EN.pdf?ua=1 [Accessed 1. December 2016].

World Health Organisation (2007) People-Centred Health Care: A policy framework. From http://www.wpro.who.int/health_services/people_at_the_centre_of_care/documents/ENGPCIPolicyFramework.pdf. [Accessed 1. December 2016].

Figure 1. Person-centred practice Framework re-presented (McCormack \& McCance 2017, p. 264)

Figure 2. PRISMA 2009 Flow Diagram of selection process

This article is protected by copyright. All rights reserved. 


\section{Table 1. Inclusion/exclusion criteria}

\begin{tabular}{|l|l|}
\hline Inclusion criteria & Exclusion criteria \\
\hline Reported primary research & $\begin{array}{l}\text { Studies in other languages than English or a } \\
\text { Scandinavian language }\end{array}$ \\
\hline $\begin{array}{l}\text { Presented data related to care partners to of older } \\
\text { person (median age 65 years of age or older) } \\
\text { living at home and receiving home care services }\end{array}$ & Palliative care \\
\hline Presented the care partners needs & \\
\hline Peer-reviewed articles & \\
\hline $\begin{array}{l}\text { Studies using qualitative/quantitative/mixed } \\
\text { methods were eligible for inclusion }\end{array}$ & \\
\hline Study published between 2000 and 2016 & \\
\hline
\end{tabular}

Table 2. JBI QARI Data Extraction Form for Interpretive and Critical research

\begin{tabular}{|c|c|c|c|c|}
\hline $\begin{array}{l}\text { Authors, } \\
\text { year and } \\
\text { country }\end{array}$ & $\begin{array}{l}\text { Design and } \\
\text { method }\end{array}$ & Study aim & $\begin{array}{l}\text { Sample description } \\
\text { and setting }\end{array}$ & Relevant findings \\
\hline $\begin{array}{l}\text { 1.Armstrong- } \\
\text { Esther et al. } \\
2005 \\
\text { Canada }\end{array}$ & $\begin{array}{l}\text { Quantitative } \\
\text { Longitudinal } \\
\text { study }\end{array}$ & $\begin{array}{l}\text { To monitor physical and } \\
\text { cognitive changes in a } \\
\text { population of } 330 \text { older } \\
\text { people being supported at } \\
\text { home by health services } \\
\text { and for their primary care } \\
\text { partners to determine } \\
\text { their specific needs and } \\
\text { how they coped as } \\
\text { dependency levels of } \\
\text { their care-recipients } \\
\text { changed. }\end{array}$ & $\begin{array}{l}\text { Initially } \\
210 \text { care partners } \\
\text { (330 care receivers) } \\
\text { Complete longitudinal } \\
\text { data sets on } \\
234 \text { care receivers and } \\
81 \text { care partners. } \\
\text {------ } \\
\text { Mean age care partners } \\
63,2 \text { to } 65,5 \text { over the } \\
\text { period of the study. } \\
\text {------- } \\
\text { In average } \\
29 \% \text { males }\end{array}$ & $\begin{array}{l}25 \% \text { of respondents } \\
\text { didn't feel they didn't get } \\
\text { enough time away from } \\
\text { caregiving. When it comes } \\
\text { to training and education, } \\
\text { the area of greatest need is } \\
\text { how to manage their own } \\
\text { stress. Training in basic } \\
\text { nursing and information } \\
\text { about dementia and stroke } \\
\text { were also requested. }\end{array}$ \\
\hline
\end{tabular}

This article is protected by copyright. All rights reserved. 


\begin{tabular}{|c|c|c|c|c|}
\hline & & & $\begin{array}{l}71 \% \text { females. } \\
48 \% \text { daughters } \\
32 \% \text { spouses } \\
12 \% \text { sons } \\
\text {------ } \\
\text { No specific information } \\
\text { about care receivers } \\
\text { disease }\end{array}$ & \\
\hline $\begin{array}{l}\text { 2.Efraimsson } \\
\text { et al. } \\
2001 \\
\text { Sweden }\end{array}$ & $\begin{array}{l}\text { Qualitative } \\
\text { unstructured } \\
\text { interviews. } \\
\text { The text was } \\
\text { analyzed by a } \\
\text { phenomenologic } \\
\text { al hermeneutic } \\
\text { approach, } \\
\text { inspired by } \\
\text { Ricoeur }\end{array}$ & $\begin{array}{l}\text { The aim of this study was } \\
\text { to describe and interpret } \\
\text { patients' and their family } \\
\text { members' lived } \\
\text { experiences of caring at } \\
\text { home }\end{array}$ & $\begin{array}{l}5 \text { care partners } \\
\text { (7 care receivers) } \\
\text { The ages of care } \\
\text { partners varied from } 45 \\
\text { to } 90 \text { years. } \\
\text {------- } \\
3 \text { male } \\
2 \text { female } \\
\text {------ } \\
3 \text { spouses } \\
1 \text { sister } \\
1 \text { son } \\
\text { Diabetes, heart and } \\
\text { vascular disorders, } \\
\text { Alzheimer's decease, } \\
\text { renal failure and stroke } \\
\text { The patients suffered } \\
\text { from diseases such as }\end{array}$ & $\begin{array}{l}\text { The findings revealed life } \\
\text { situations where natural } \\
\text { caring was changed into } \\
\text { patient-care-giver } \\
\text { relations and the home } \\
\text { became a public room. } \\
\text { The family members had } \\
\text { to deal with adjusting to } \\
\text { caring needs. Care } \\
\text { partners ended up being } \\
\text { more or less } \\
\text { indispensable. Participants } \\
\text { strove to master new skills } \\
\text { but did not always reach } \\
\text { the goal. Participants took } \\
\text { on vast responsibilities } \\
\text { within the care situation }\end{array}$ \\
\hline $\begin{array}{l}\text { 3.Gjevjon et } \\
\text { al. } \\
2016\end{array}$ & $\begin{array}{l}\text { Quantitative } \\
\text { cross-sectional } \\
\text { study. }\end{array}$ & $\begin{array}{l}\text { To explore how patients } \\
\text { and next of kin } \\
\text { experience and assess } \\
\text { continuity when patients } \\
\text { receive daily and long- }\end{array}$ & $\begin{array}{l}75 \text { care partners } \\
\text { ( } 75 \text { care receivers) } \\
\text {------- }\end{array}$ & $\begin{array}{l}\text { Care partners are more } \\
\text { likely to accept a high } \\
\text { number of carers if carers } \\
\text { were informed about the } \\
\text { patient's situation. }\end{array}$ \\
\hline
\end{tabular}

This article is protected by copyright. All rights reserved. 


\begin{tabular}{|c|c|c|c|c|}
\hline Norway & & $\begin{array}{l}\text { term home health care } \\
\text { from multiple health } \\
\text { personnel. }\end{array}$ & $\begin{array}{l}\text { Mean age care partners } \\
59,9 \text { years } \\
\text {----- } \\
37 \% \text { male } \\
63 \% \text { female } \\
------ \\
\text { Spouse } 20 \% \text {, } \\
\text { Children/children -in- } \\
\text { law 65\%, } \\
\text { Extended family } 15 \% \\
------ \\
\text { No specific information } \\
\text { about care receivers } \\
\text { disease }\end{array}$ & \\
\hline $\begin{array}{l}\text { 4.Hautsalo et } \\
\text { al. } \\
2013 \\
\text { Finland }\end{array}$ & Quantitative & $\begin{array}{l}\text { To describe aged home } \\
\text { care clients' and their } \\
\text { family members' } \\
\text { experiences of their } \\
\text { family functioning, } \\
\text { family health and social } \\
\text { support received. An } \\
\text { additional purpose was to } \\
\text { determine which factors } \\
\text { are connected with social } \\
\text { support. }\end{array}$ & $\begin{array}{l}83 \text { care partners } \\
\text { (82 care receivers) } \\
\text { Mean age care partners } \\
60,2 \text { years } \\
----- \\
27 \% \text { male } \\
74 \% \text { (sic) female } \\
------ \\
\text { Children } 66 \%, \\
\text { Spouse } 12 \% \\
\text { Siblings, friends, } \\
\text { neighbours etc. } 22 \% \\
------ \\
\text { No specific information } \\
\text { about care receivers } \\
\text { disease }\end{array}$ & $\begin{array}{l}\text { Home care clients' and } \\
\text { care partners need for } \\
\text { support vary and require } \\
\text { flexible and adaptable } \\
\text { home services. }\end{array}$ \\
\hline
\end{tabular}

This article is protected by copyright. All rights reserved. 


\begin{tabular}{|c|c|c|c|c|}
\hline $\begin{array}{l}\text { 5.Hegli \& Foss } \\
2009 \\
\text { Norway }\end{array}$ & $\begin{array}{l}\text { Qualitative, } \\
\text { In-depth semi } \\
\text { structured } \\
\text { interviews. } \\
\text { Transverse and } \\
\text { lengthwise } \\
\text { analysis } \\
\text { processes as } \\
\text { described by } \\
\text { Malterud and } \\
\text { Søndergaard. }\end{array}$ & $\begin{array}{l}\text { To describe how elderly } \\
\text { spousal care partners } \\
\text { experience participation } \\
\text { in the decision making } \\
\text { process with the home } \\
\text { nursing care. }\end{array}$ & $\begin{array}{l}9 \text { care partners } \\
\text { Mean age care partners } \\
81 \text { years } \\
------ \\
5 \text { males } \\
4 \text { females } \\
------ \\
\text { All spouses } \\
\text {------ } \\
\text { No specific information } \\
\text { about care receivers } \\
\text { disease }\end{array}$ & $\begin{array}{l}\text { Care partners show signs } \\
\text { of an exhausting and } \\
\text { isolated existence where } \\
\text { they receive little support. } \\
\text { The time of delivery of } \\
\text { services is a key issue- } \\
\text { Spouses' strategies of } \\
\text { participation are often } \\
\text { subtle and cautious, and } \\
\text { the spouses lose the } \\
\text { negotiations in most cases. }\end{array}$ \\
\hline $\begin{array}{l}\text { 6.Landmark et } \\
\text { al. } \\
2013 \\
\text { Norway }\end{array}$ & $\begin{array}{l}\text { Qualitative } \\
\text { Focus group } \\
\text { interviews } \\
\text { Method for data } \\
\text { analysis was } \\
\text { content analysis } \\
\text { and meaning } \\
\text { condensation }\end{array}$ & $\begin{array}{l}\text { To describe and explore } \\
\text { relatives' experiences of } \\
\text { dementia suffers living at } \\
\text { home and to reveal } \\
\text { relatives' needs for } \\
\text { assistance and support }\end{array}$ & $\begin{array}{l}10 \text { care partners } \\
\text { Mean age care partners } \\
53,7 \text { years } \\
---- \\
2 \text { males } \\
8 \text { females } \\
---- \\
2 \text { sons } \\
7 \text { daughters } \\
1 \text { daughter-in-law } \\
----- \\
\text { The care receivers had } \\
\text { dementia }\end{array}$ & $\begin{array}{l}\text { Care partners are unable } \\
\text { to escape the situation, } \\
\text { and they experience a } \\
\text { sense of powerlessness } \\
\text { due to fragmented } \\
\text { services. Care partners } \\
\text { care burden and } \\
\text { powerlessness can be } \\
\text { remedied through the } \\
\text { assessment of their } \\
\text { situation by home care } \\
\text { services, and through the } \\
\text { tailoring of assistance } \\
\text { based on individual needs. }\end{array}$ \\
\hline $\begin{array}{l}\text { 7.Leiknes and } \\
\text { Høye } \\
2012 \\
\text { Norway }\end{array}$ & $\begin{array}{l}\text { Qualitative } \\
\text { Interviews } \\
\text { Interpretative } \\
\text { approach to the }\end{array}$ & $\begin{array}{l}\text { To explore how family } \\
\text { Parkinson's disease care } \\
\text { givers (PD) experience } \\
\text { their situation when they } \\
\text { share caring with the } \\
\text { home care services }\end{array}$ & $\begin{array}{l}9 \text { care partners } \\
\text { Age spouse } 61-83 \\
\text { Age adult child } 44-59\end{array}$ & $\begin{array}{l}\text { Care partners have } \\
\text { challenges with clarifying } \\
\text { and delimiting } \\
\text { responsibility. The home } \\
\text { care services' need for a } \\
\text { flexible schedule } \\
\text { competed with the care } \\
\text { partners need for a }\end{array}$ \\
\hline
\end{tabular}

This article is protected by copyright. All rights reserved. 


\begin{tabular}{|c|c|c|c|c|}
\hline & $\begin{array}{l}\text { analysis based } \\
\text { on a } \\
\text { phenomenologic } \\
\text { al and } \\
\text { hermeneutic } \\
\text { philosophy. }\end{array}$ & & $\begin{array}{l}3 \text { males } \\
6 \text { females } \\
\text {------ } \\
6 \text { spouses } \\
3 \text { adult child } \\
------ \\
\text { All of the care receivers } \\
\text { had PD. }\end{array}$ & $\begin{array}{l}\text { professional, trustworthy, } \\
\text { predictable and flexible } \\
\text { service. }\end{array}$ \\
\hline $\begin{array}{l}\text { 8.McCaffrey et } \\
\text { al. } \\
2015 \\
\text { Australia }\end{array}$ & $\begin{array}{l}\text { Qualitative } \\
\text { Semi-structured } \\
\text { interviews. } \\
\text { Descriptive } \\
\text { analysis }\end{array}$ & $\begin{array}{l}\text { To determine what } \\
\text { features of consumer- } \\
\text { directed, home-based } \\
\text { support services are } \\
\text { important to older people } \\
\text { and their care partners to } \\
\text { inform the design of a } \\
\text { discrete choice } \\
\text { experiment }\end{array}$ & $\begin{array}{l}10 \text { care partners } \\
\text { (17 care receivers) } \\
\text { Age range care partners } \\
51-90 \text { years } \\
------ \\
3 \text { male } \\
7 \text { female } \\
------ \\
50 \% \text { spouse } \\
50 \% \text { children } \\
------ \\
\text { No specific information } \\
\text { about care receivers } \\
\text { disease }\end{array}$ & $\begin{array}{l}\text { Eight broad themes were } \\
\text { identified; information } \\
\text { and knowledge, choice } \\
\text { and control, self-managed } \\
\text { continuum, effective co- } \\
\text { ordination and } \\
\text { communication, } \\
\text { responsiveness and } \\
\text { flexibility, continuity and } \\
\text { planning. }\end{array}$ \\
\hline $\begin{array}{l}\text { 9.McCormack } \\
\& \text { Skatvedt } \\
2016 \\
\text { Norway }\end{array}$ & $\begin{array}{l}\text { Qualitative } \\
\text { Semi-structured } \\
\text { interviews. } \\
\text { Inductive } \\
\text { approach to the }\end{array}$ & $\begin{array}{l}\text { To explore how older } \\
\text { people living at home } \\
\text { with mental health needs } \\
\text { and their care partners } \\
\text { experienced the practices } \\
\text { of collaboration within } \\
\text { and between services }\end{array}$ & $\begin{array}{l}5 \text { care partners } \\
(16 \text { care receivers }) \\
------ \\
4 \text { males } \\
1 \text { female }\end{array}$ & $\begin{array}{l}\text { Older people and their } \\
\text { care partners experience } \\
\text { discontinuities in their } \\
\text { everyday interaction with } \\
\text { care workers. They need } \\
\text { high levels of energy to } \\
\text { express needs and have } \\
\text { them met in a way that } \\
\text { reflects principles of }\end{array}$ \\
\hline
\end{tabular}

This article is protected by copyright. All rights reserved. 


\begin{tabular}{|c|c|c|c|c|}
\hline & $\begin{array}{l}\text { analysis as } \\
\text { described by } \\
\text { Patton. }\end{array}$ & & $\begin{array}{l}\text { All of the care receivers } \\
\text { had mental health } \\
\text { problems }\end{array}$ & $\begin{array}{l}\text { partnership working. } \\
\text { Strategies for } \\
\text { empowerment are needed. }\end{array}$ \\
\hline $\begin{array}{l}\text { 10.Ploeg et al. } \\
2001 \\
\text { Canada }\end{array}$ & $\begin{array}{l}\text { Qualitative } \\
\text { Semi-structured } \\
\text { interviews. } \\
\text { Thematic } \\
\text { analysis }\end{array}$ & $\begin{array}{l}\text { To address two research } \\
\text { questions; what are the } \\
\text { perceived support needs } \\
\text { of family care partners of } \\
\text { older persons who are } \\
\text { living with chronic } \\
\text { illness and receiving } \\
\text { home care services? } \\
\text { What types of telephone } \\
\text { support services would } \\
\text { meet the perceived needs } \\
\text { of care partners? }\end{array}$ & $\begin{array}{l}34 \text { care partners } \\
\text { Mean age care partners } \\
62,3 \text { years } \\
12 \text { males } \\
22 \text { females } \\
----- \\
17 \text { Spouses } \\
17 \text { children, } \\
1 \text { parent } \\
------ \\
\text { All care receivers had a } \\
\text { chronic physical or } \\
\text { mental health problems }\end{array}$ & $\begin{array}{l}\text { The most commonly } \\
\text { expressed needs of the } \\
\text { care partners were: a } \\
\text { social life, instrumental } \\
\text { support (e.g., respite, } \\
\text { assistance with physical } \\
\text { care, financial } \\
\text { compensation), } \\
\text { informational support and } \\
\text { emotional support. }\end{array}$ \\
\hline $\begin{array}{l}\text { 11.Saunders } \\
2012 \\
\text { USA }\end{array}$ & $\begin{array}{l}\text { Qualitative } \\
\text { Interviews. } \\
\text { Emergent } \\
\text { design. } \\
\\
\text { Line-by-line } \\
\text { method of } \\
\text { analysis }\end{array}$ & $\begin{array}{l}\text { To explore the meaning } \\
\text { of being a heart failure } \\
\text { (HF) caregiver while } \\
\text { receiving home care } \\
\text { nursing services. }\end{array}$ & $\begin{array}{l}11 \text { care partners } \\
11 \text { care receivers } \\
\text { Mean age care partners } \\
66 \text { years } \\
---- \\
4 \text { male. } \\
7 \text { female } \\
------ \\
8 \text { spouses } \\
3 \text { children } \\
------ \\
\text { All of the care receivers }\end{array}$ & $\begin{array}{l}\text { The needs of the care } \\
\text { partners were family } \\
\text { support, nursing/ } \\
\text { telemanagement support, } \\
\text { and respite. }\end{array}$ \\
\hline
\end{tabular}

This article is protected by copyright. All rights reserved. 


\begin{tabular}{|c|c|c|c|c|}
\hline & & & had HF. & \\
\hline $\begin{array}{l}\text { 12.Sims-Gould } \\
\text { \& Martin- } \\
\text { Matthews } \\
2010 \\
\text { Canada }\end{array}$ & $\begin{array}{l}\text { Qualitative, } \\
\text { In-depth semi } \\
\text { structured } \\
\text { interviews. } \\
\text { The analysis } \\
\text { was guided by } \\
\text { Sims-Gould \& } \\
\text { Martin- } \\
\text { Matthews } \\
\text { conceptual } \\
\text { model }\end{array}$ & $\begin{array}{l}\text { 1. To extend our } \\
\text { understanding of the } \\
\text { salient issues in delivery } \\
\text { of home support from the } \\
\text { perspective of family } \\
\text { care partners. } \\
\text { 2. To examine the } \\
\text { contributions and } \\
\text { dynamics between family } \\
\text { care partners and home } \\
\text { support workers. }\end{array}$ & $\begin{array}{l}56 \text { care partners } \\
\text { Mean age care partners } \\
68 \text { years } \\
9 \text { male } \\
43 \text { female } \\
------- \\
24 \text { spouses } \\
20 \text { sons/daughters } \\
8 \text { other } \\
------- \\
\text { No specific information } \\
\text { about care receivers } \\
\text { disease. }\end{array}$ & $\begin{array}{l}\text { Care partners emphasised } \\
\text { dissatisfaction with } \\
\text { instrumental assistance } \\
\text { provided by home care } \\
\text { services, while also } \\
\text { stressing the importance } \\
\text { of affective (relationship } \\
\text { aspect) assistance. Care } \\
\text { partners bear the burden } \\
\text { of reduced hours, rotating } \\
\text { schedules and lack of } \\
\text { continuity. The } \\
\text { importance of providing } \\
\text { relief for care partners is } \\
\text { highlighted. }\end{array}$ \\
\hline $\begin{array}{l}\text { 13.Sooden et } \\
\text { al. } \\
2007 \\
\text { Canada }\end{array}$ & $\begin{array}{l}\text { Qualitative, } \\
\text { Semi structured } \\
\text { interviews. } \\
\text { Thematic } \\
\text { content analysis }\end{array}$ & $\begin{array}{l}\text { To explore the home care } \\
\text { experience as described } \\
\text { by older care receivers } \\
\text { and their care partner. }\end{array}$ & $\begin{array}{l}9 \text { care partners } \\
\text { (9 care receivers) } \\
\text { Mean age care partners } \\
78 \text { years } \\
6 \text { males } \\
3 \text { females } \\
------ \\
9 \text { spouses } \\
\text {------ } \\
\text { At least one chronic } \\
\text { disability or illness. }\end{array}$ & $\begin{array}{l}\text { Two major themes } \\
\text { identified; relief and } \\
\text { continuity. Subthemes; } \\
\text { respite and physical } \\
\text { safety, living } \\
\text { independently, lifestyle } \\
\text { challenges (the need for } \\
\text { getting help when needed) } \\
\text { and the wish for having } \\
\text { the same home care } \\
\text { workers over time. }\end{array}$ \\
\hline $\begin{array}{l}\text { 14.Van } \\
\text { Houtven et al. }\end{array}$ & $\begin{array}{l}\text { Quantitative } \\
\text { questionnaires. }\end{array}$ & $\begin{array}{l}\text { To describe the informal } \\
\text { and formal care } \\
\text { infrastructure among }\end{array}$ & 17 care partners & $\begin{array}{l}\text { Caregiver perceived need } \\
\text { for training were } \\
\text { organizing preventive care }\end{array}$ \\
\hline
\end{tabular}

This article is protected by copyright. All rights reserved. 


\begin{tabular}{|c|c|c|c|c|}
\hline $\begin{array}{l}2010 \\
\text { USA }\end{array}$ & $\begin{array}{l}\text { Descriptive } \\
\text { statistics and } \\
\text { chi-squared } \\
\text { tests. }\end{array}$ & $\begin{array}{l}\text { veterans and the } \\
\text { perceived need for } \\
\text { caregiver training among } \\
\text { veterans and care } \\
\text { partners. }\end{array}$ & $\begin{array}{l}\text { Mean age care partners } \\
66,63 \text { years } \\
------ \\
47 \text { spouses } \\
19 \text { children } \\
2 \text { parents } \\
7 \text { sibling/friend } \\
14 \text { unknown } \\
------ \\
\text { Care receivers suffered } \\
\text { from multiple } \\
\text { limitations and chronic } \\
\text { illnesses. }\end{array}$ & $\begin{array}{l}\text { for veterans, supporting } \\
\text { self-care and cooping with } \\
\text { caregiving. Learning how } \\
\text { to get more services for } \\
\text { the care receiver was also } \\
\text { found to be important. }\end{array}$ \\
\hline $\begin{array}{l}\text { 15. Wester et } \\
\text { al. } \\
2013 \\
\text { Sweden }\end{array}$ & $\begin{array}{l}\text { Qualitative } \\
\text { Semi-structured } \\
\text { interviews. } \\
\text { Content analysis }\end{array}$ & $\begin{array}{l}\text { To explore how care } \\
\text { partners experience } \\
\text { caring for an elderly } \\
\text { relative in ordinary } \\
\text { living. }\end{array}$ & $\begin{array}{l}11 \text { care partners } \\
\text {----- } \\
3 \text { males } \\
8 \text { females } \\
----- \\
10 \text { spouses } \\
1 \text { son } \\
------ \\
\begin{array}{l}\text { Dementia and/or } \\
\text { physical disability. }\end{array}\end{array}$ & $\begin{array}{l}\text { The needs of the care } \\
\text { partners fell into three } \\
\text { categories; the need for } \\
\text { belonging to someone, the } \\
\text { need for controlling one's } \\
\text { everyday life and the need } \\
\text { for social support. }\end{array}$ \\
\hline $\begin{array}{l}\text { 16. Wilkins et } \\
\text { al. } \\
2009 \\
\text { USA }\end{array}$ & $\begin{array}{l}\text { Quantitative } \\
\text { questionnaires } \\
\text { and measures. } \\
\\
\text { Data were } \\
\text { analyzed using } \\
\text { SPSS software* }\end{array}$ & $\begin{array}{l}\text { This study assessed the } \\
\text { caregiving activities and } \\
\text { training interests of } \\
\text { family care partners of } \\
\text { medically ill older adults } \\
\text { without dementia who } \\
\text { receive home health care. }\end{array}$ & $\begin{array}{l}101 \text { care partners } \\
\text { Mean age care partners } \\
62,91 \text { years } \\
------ \\
25 \text { male } \\
76 \text { female } \\
------ \\
52 \text { same generation as } \\
\text { care receiver (for }\end{array}$ & $\begin{array}{l}\text { The major findings are } \\
\text { that care partners provide } \\
\text { a large range of caregiving } \\
\text { tasks and many are } \\
\text { interested in learning to } \\
\text { provide more tasks and/or } \\
\text { become more effective in } \\
\text { providing caregiving } \\
\text { tasks. }\end{array}$ \\
\hline
\end{tabular}

This article is protected by copyright. All rights reserved. 


\begin{tabular}{|l|l|l|l|}
\hline & $\mid \begin{array}{l}\text { example spouse, } \\
\text { significant other, sister, } \\
\text { cousin, friend) } \\
49 \text { one or two } \\
\text { generations younger (for } \\
\text { example adult child, } \\
\text { niece, daughter-in-law, } \\
\text { and granddaughter). }\end{array}$ \\
& $\begin{array}{l}\text { Multiple chronic } \\
\text { illnesses, cardiovascular } \\
\text { problems being the most } \\
\text { common. }\end{array}$ & \\
\hline
\end{tabular}

Table 3. Quality assessment of the included studies

\begin{tabular}{|c|c|c|c|c|c|c|c|c|c|c|}
\hline \multicolumn{11}{|c|}{ 3A.) JBI Critical Appraisal Checklist for Qualitative studies } \\
\hline \multirow[t]{2}{*}{ Study } & \multicolumn{9}{|c|}{ Criteria* } & \multirow[t]{2}{*}{ Total/10 } \\
\hline & 1 & 23 & 34 & 45 & 6 & 7 & 8 & 9 & 10 & \\
\hline Efraimsson et al. (2001) & + & $+\quad+$ & $+\quad+$ & + & - & - & + & + & + & 8 \\
\hline Hegli \& Foss (2009) & - & $+\quad+$ & $+\quad+$ & + & - & - & + & + & + & 7 \\
\hline Landmark et al. (2013) & - & $+\quad+$ & $+\quad+$ & + & - & - & + & + & + & 7 \\
\hline Leiknes and Høye (2012) & + & $+\quad+$ & $+\quad+$ & + & + & + & + & + & + & 10 \\
\hline McCaffrey et al. (2015) & + & $+\quad+$ & $+\quad+$ & ++ & - & - & + & + & + & 9 \\
\hline McCormack \& Skatvedt (2016) & - & $+\quad+$ & $+\quad+$ & $+\quad+$ & - & - & + & + & + & 7 \\
\hline Ploeg et al. (2001) & - & $+\quad+$ & $+\quad+$ & $+\quad+$ & - & - & + & + & + & 7 \\
\hline Saunders (2012) & + & $+\quad+$ & $+\quad+$ & ++ & - & - & + & + & + & 8 \\
\hline $\begin{array}{l}\text { Sims-Gould \& } \quad \text { Martin-Matthews } \\
(2010)\end{array}$ & - & $+\quad+$ & $+\quad+$ & $+\quad+$ & - & - & + & + & + & 7 \\
\hline Sooden et al. (2007) & - & + & $+\quad+$ & + & - & - & + & + & + & 7 \\
\hline Wester et al. (2013) & - & $+\quad+$ & $+\quad+$ & + & + & + & + & + & + & 9 \\
\hline
\end{tabular}

This article is protected by copyright. All rights reserved. 
*1.) Congruity between stated philosophical perspective and the research methodology 2.) Congruity between research methodology and research question 3.) Congruity between research methodology and methods for collecting data 4.) Congruity between research methodology and the representation of the analysis 5.) Congruity between research methodology and the interpretation of results 6.) Statement locating the researcher culturally or theoretically 7.) Influence of the researcher on the research and viceversa addressed 8.) Participants and their voices adequately represented 9.) Is the research ethical according to current criteria or, evidence of ethical approval by an appropriate body 10.) Conclusion drawn from the analysis or interpretation of the data

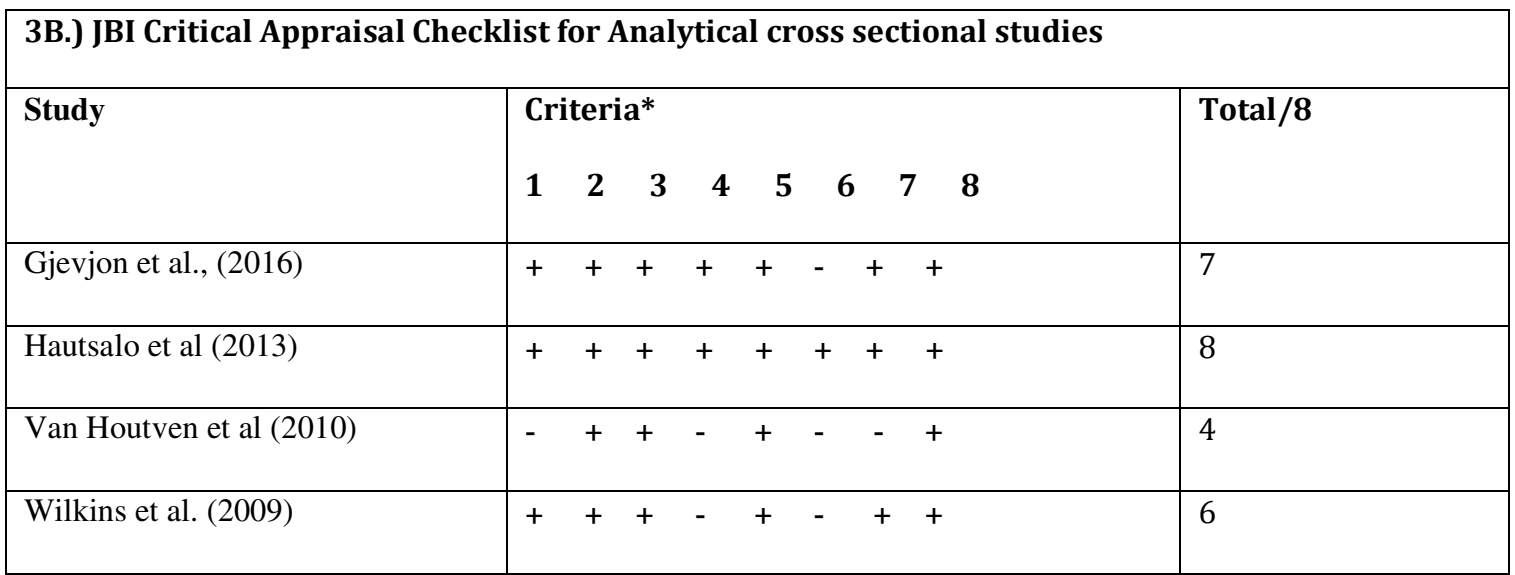

*1.) Inclusion criteria clearly defined 2.) Study subjects and setting described in detail 3.) Exposure measured in a valid and reliable way 4.) Objective, standard criteria used for measurement of the condition 5.) Confounding factors identified 6.) Strategies to deal with confounding factors stated 7.) Outcomes measured in a valid and reliable way 8.) Appropriate statistical analysis used.

\section{C.) JBI Critical Appraisal Checklist for Cohort studies}

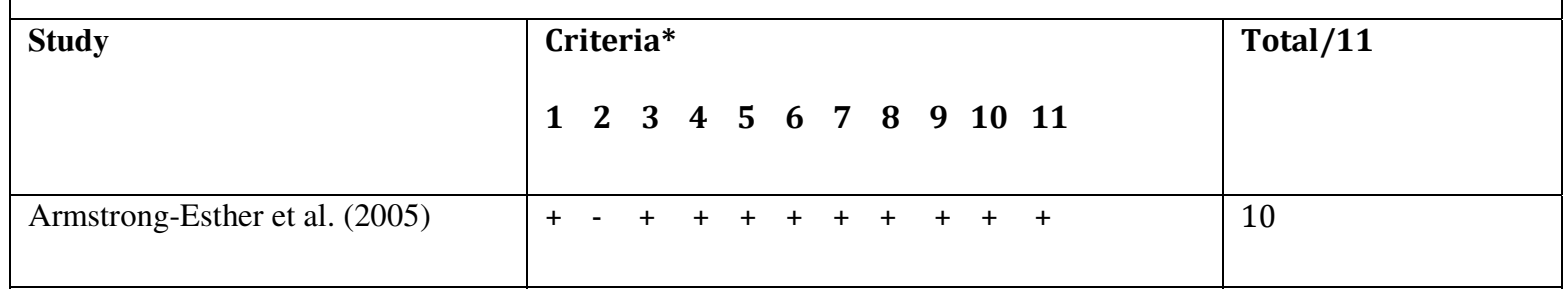

*1.) Groups similar and recruited from same population 2.) Exposures measured similarly to assign people to both exposed and unexposed groups 3.) Exposure measured in a valid and reliable way 4.) Confounding factors identified 5.) Strategies to deal with confounding factors stated 6.) Groups/participants free of the outcome at the start of the study 7.) Outcomes measured in a valid and reliable way 8.) Follow up time reported and sufficient to belong enough for outcomes to occur 9.) Follow-up complete, if not, reasons to loss to follow-up described and explored 10.) Strategies to address incomplete follow-up used 11.) Appropriate statistical analysis used.

This article is protected by copyright. All rights reserved. 
Table 4. Results

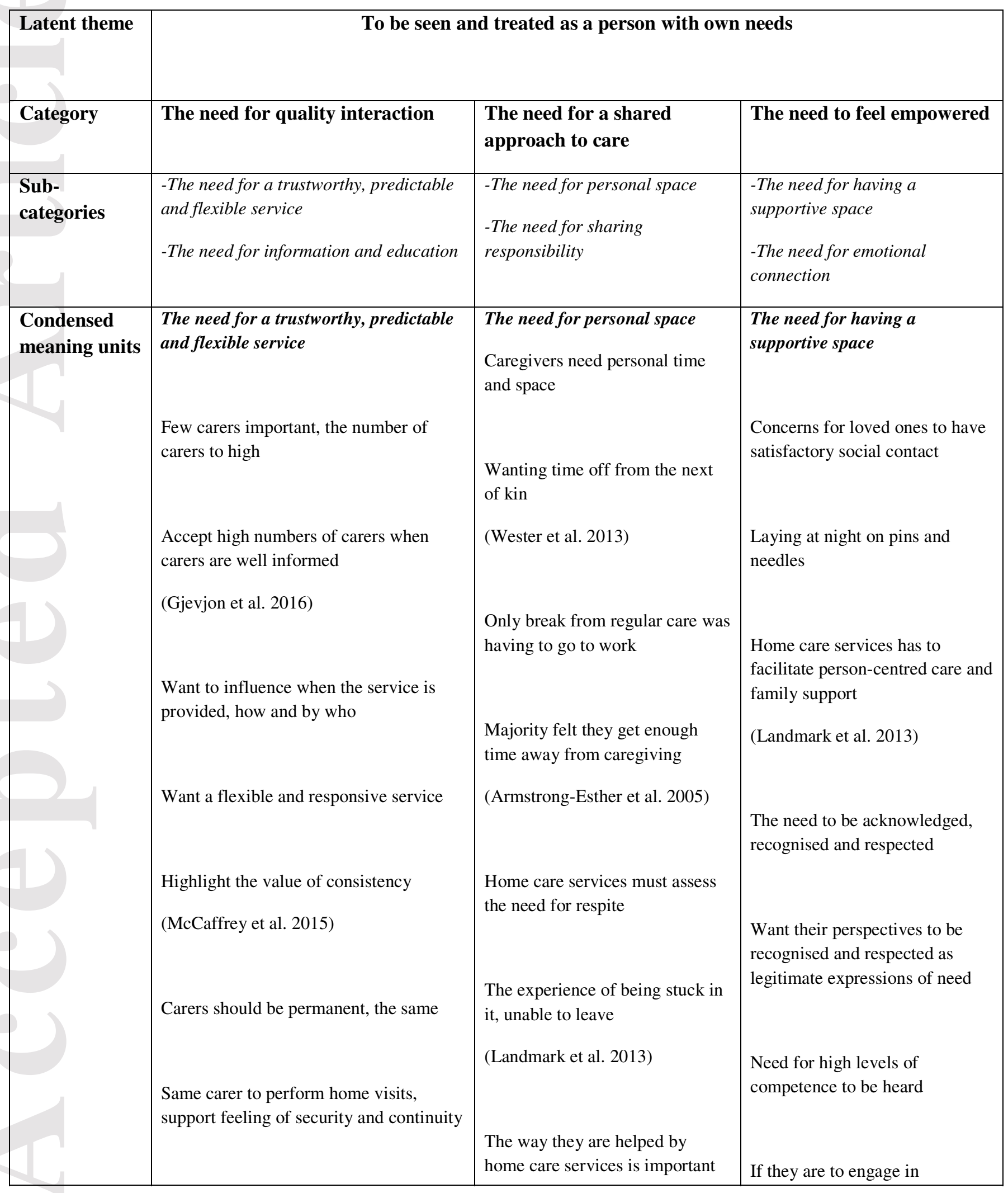

This article is protected by copyright. All rights reserved. 


\begin{tabular}{|c|c|c|}
\hline $\begin{array}{l}\text { Flexible time for visits, primary nursing } \\
\text { and minimal turnover (Hautsalo et al. } \\
\text { 2013) }\end{array}$ & $\begin{array}{l}\text { for the feeling of relief } \\
\text { (Leiknes \& Høye 2012) }\end{array}$ & $\begin{array}{l}\text { collaboration, strategies to } \\
\text { empower them are needed } \\
\text { (McCormack \& Skatvedt 2016) }\end{array}$ \\
\hline $\begin{array}{l}\text { Wish for a greater degree of continuity in } \\
\text { care, burden with many different carers }\end{array}$ & $\begin{array}{l}\text { Gaining respite was perceived as } \\
\text { the most important caregiver } \\
\text { need }\end{array}$ & $\begin{array}{l}\text { Effective co-ordination of } \\
\text { services central for satisfying } \\
\text { individuals' needs }\end{array}$ \\
\hline $\begin{array}{l}\text { Continuity of care is a prerequisite for } \\
\text { family support } \\
\text { (Landmark et al. 2013) }\end{array}$ & $\begin{array}{l}\text { I have no time to myself } \\
\text { (Saunders 2012) } \\
\text { Having a break rejuvenated them }\end{array}$ & $\begin{array}{l}\text { Having choice and control } \\
\text { promoted well-being } \\
\text { (McCaffrey et al. 2015) }\end{array}$ \\
\hline $\begin{array}{l}\text { To feel safe, the service has to be } \\
\text { predictable }\end{array}$ & $\begin{array}{l}\text { 'Stolen moments', essential to } \\
\text { their own emotional and mental } \\
\text { health } \\
\text { (Sooden et al. 2007) }\end{array}$ & $\begin{array}{l}\text { Wanted support from } \\
\text { professionals with experience } \\
\text { and knowledge about disease }\end{array}$ \\
\hline $\begin{array}{l}\text { Need to have full control over medicine } \\
\text { nurses were often late }\end{array}$ & $\begin{array}{l}\text { The most commonly expressed } \\
\text { need was the need for a social } \\
\text { life } \\
\text { Craved more time away }\end{array}$ & $\begin{array}{l}\text { Meet caregivers need for a } \\
\text { service that balance competing } \\
\text { needs and ease troubled } \\
\text { conscience } \\
\text { (Leiknes \& Høye 2012) }\end{array}$ \\
\hline $\begin{array}{l}\text { Wanted skilled professional carers } \\
\text { (Leiknes \& Høye 2012) }\end{array}$ & (Ploeg et al. 2001) & $\begin{array}{l}\text { Need for caregiver relief, } \\
\text { assistance physical care, } \\
\text { financial compensation and more } \\
\text { hours of support }\end{array}$ \\
\hline $\begin{array}{l}\text { Focus on the quality of interaction } \\
\text { (McCormack \&Skatvedt 2016) }\end{array}$ & $\begin{array}{l}\text { The need for sharing } \\
\text { responsibility } \\
\text { Cooperation between all } \\
\text { participants in care } \\
\text { (Hautsalo et al. 2013). }\end{array}$ & $\begin{array}{l}\text { All who received } \\
\text { telemanagement found it to be a } \\
\text { benefit and made them feel more } \\
\text { secure }\end{array}$ \\
\hline 'Would be so nice to have continuity' & $\begin{array}{l}\text { Assessment of relatives' situation } \\
\text { and individually help to alleviate }\end{array}$ & \\
\hline
\end{tabular}

This article is protected by copyright. All rights reserved. 


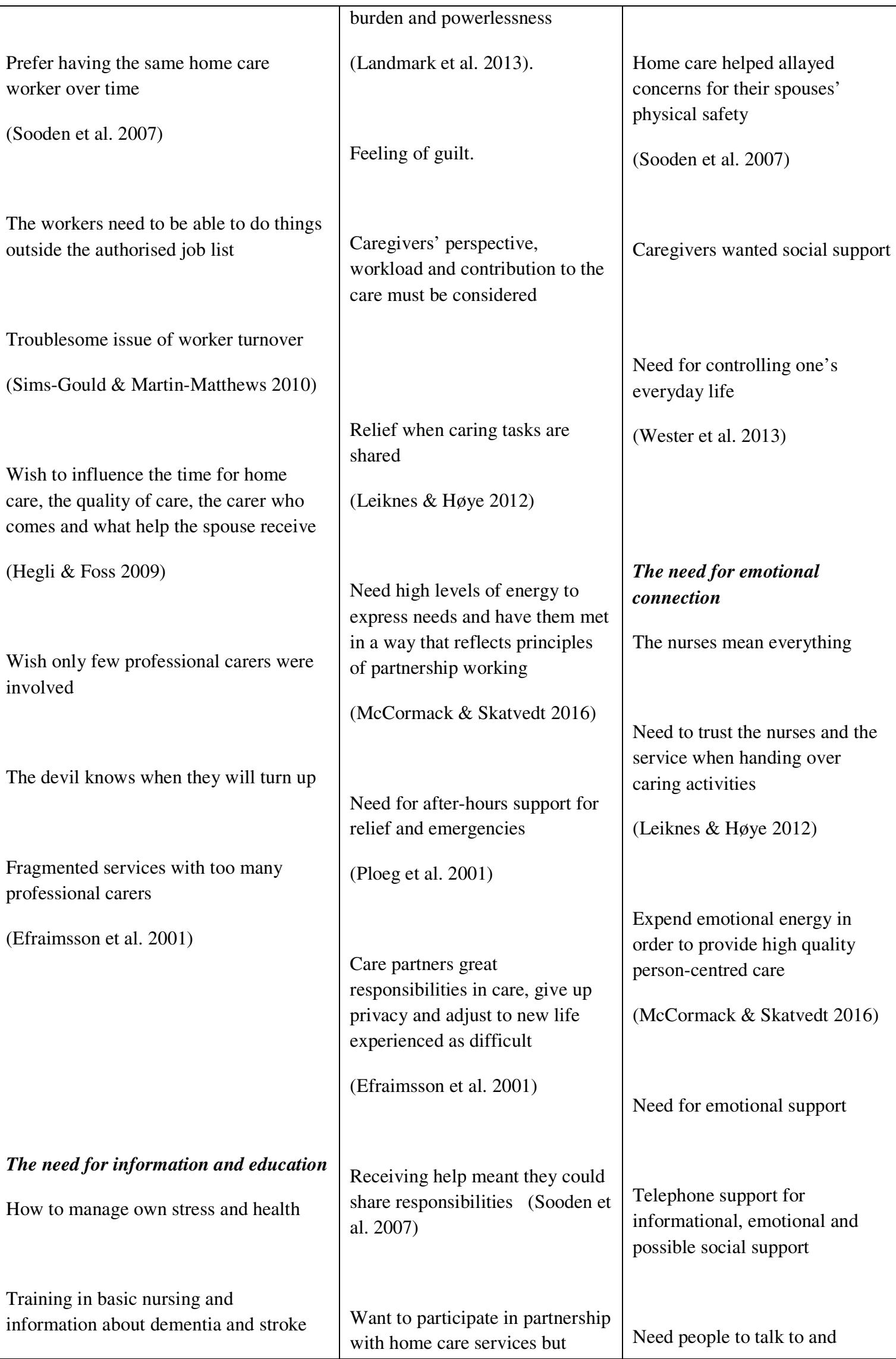

This article is protected by copyright. All rights reserved. 


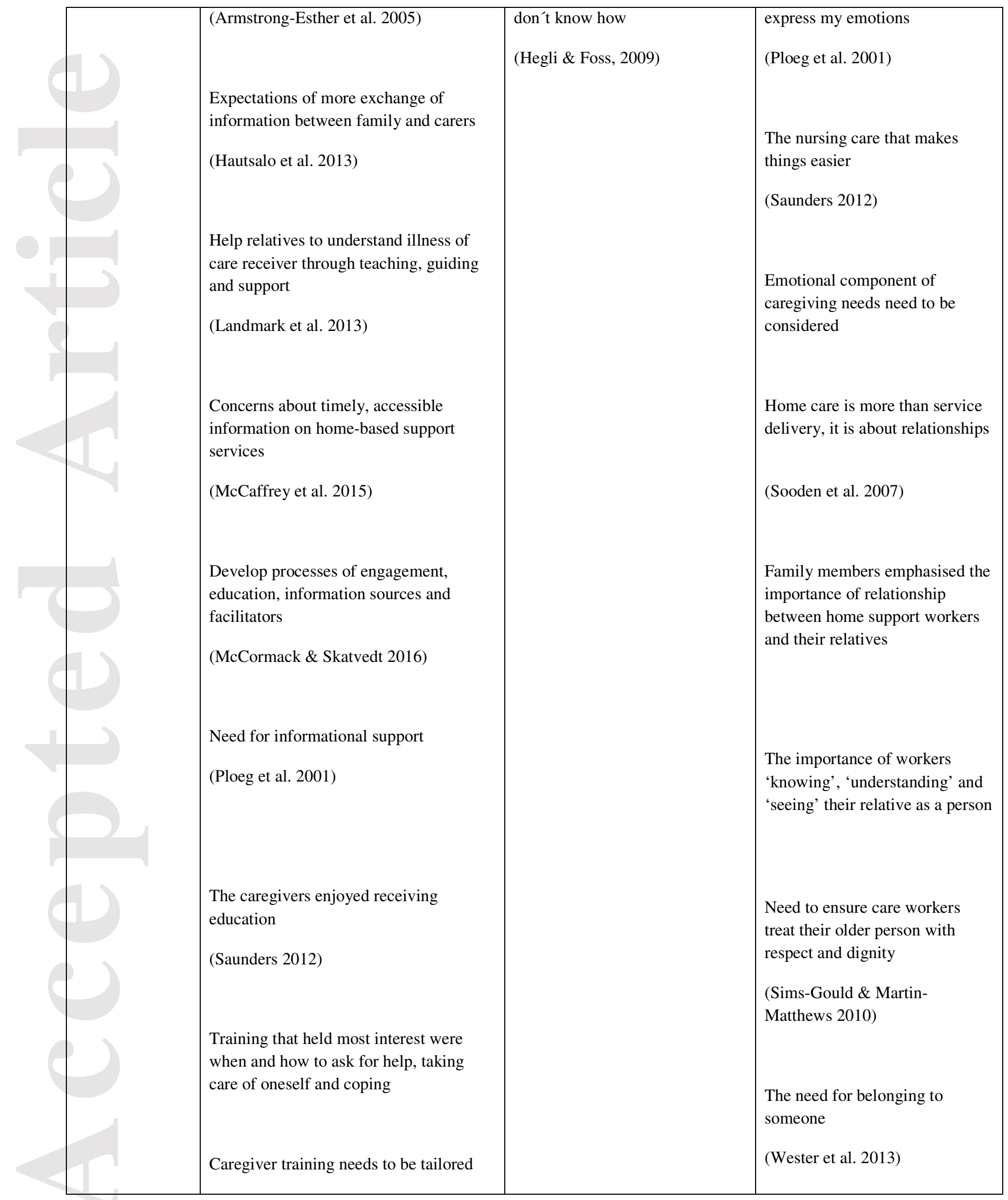

This article is protected by copyright. All rights reserved. 


\begin{tabular}{|l|l|l|l|}
\hline & $\begin{array}{l}\text { (Van Houtven et al. 2010) } \\
\begin{array}{l}\text { Eager to receive training to provide more } \\
\text { tasks or become more effective } \\
\text { (Wilkins et al. 2009) }\end{array}\end{array}$ & $\begin{array}{l}\text { Relationship with a close contact } \\
\text { that has extra time and provides } \\
\text { support and recognition } \\
\text { influence attempt to contribute } \\
\text { (Hegli \& Foss 2009) }\end{array}$ \\
\hline $\begin{array}{l}\text { Inadequate preparation and knowledge } \\
\text { (Efraimsson et al. 2001) }\end{array}$ & \\
\hline
\end{tabular}

\section{ADDITIONAL FILE 1. MeSH AND KEY WORDS}

\section{CINAHL}

\begin{tabular}{|c|c|c|}
\hline Care Partners & & \\
\hline CINAHL headings & Caregivers & \\
\hline & Family exp & \\
\hline Text words caregivers & Caregiver* & \\
\hline & Carer* & \\
\hline & Care giver* & \\
\hline & Informal care* & \\
\hline & Spouse caregiver* & \\
\hline & Family caregiver* & \\
\hline & Care partner* & \\
\hline Text words for family & Family & \\
\hline & Relatives & \\
\hline & Extended family & \\
\hline & Family member* & \\
\hline
\end{tabular}

This article is protected by copyright. All rights reserved. 


\begin{tabular}{|c|c|}
\hline & $\begin{array}{l}\text { Nuclear family } \\
\text { Spouse* }\end{array}$ \\
\hline \multicolumn{2}{|l|}{ Home Nursing } \\
\hline \multirow[t]{2}{*}{ CINAHL heading } & Home nursing \\
\hline & Home health care (exp only home nursing) \\
\hline \multirow[t]{11}{*}{ Text words } & Home nursing \\
\hline & Home care* \\
\hline & Homecare* \\
\hline & Home health care* \\
\hline & Home healthcare* \\
\hline & Home care service* \\
\hline & Home health nursing \\
\hline & Home based care* \\
\hline & Home based nursing \\
\hline & Domiciliary care* \\
\hline & Domestic health care* \\
\hline
\end{tabular}

\section{Medline}

\begin{tabular}{|l|l|l|}
\hline Care partners & Caregivers exp & \\
\hline MESH & Family exp & \\
\hline Text words & Same as CINAHL & \\
\hline $\begin{array}{l}\text { Text words for professional- family } \\
\text { relations }\end{array}$ & Same as CINAHL & \\
\hline Text words for family & Same as CINAHL & $\begin{array}{l}\text { Exp inc home health care and } \\
\text { home nursing }\end{array}$ \\
\hline MESH & Home care services exp & \\
\hline Text words for home care services & Same as other CINAHL \\
\hline
\end{tabular}

This article is protected by copyright. All rights reserved. 
PsycInfo

\begin{tabular}{|l|l|l|}
\hline Care partners & Caregivers exp & \\
\hline Thesaurus & Family exp & \\
\hline Text words & Same as CINAHL & \\
\hline Home nursing & Home care exp & Home nursing, home health care. \\
\hline Thesaurus & Same as CINAHL & \\
\hline Text words & & \\
\hline
\end{tabular}

Embase

Care partners

\begin{tabular}{|l|l|l|}
\hline Emtree & Caregiver exp & \\
\hline Text words & Family exp & \\
\hline Home nursing & Same as CINAHL & \\
\hline Emtree & Home care without exp & Home nursing, home health care. \\
\hline Text words & & \\
\hline
\end{tabular}

Age Line

\begin{tabular}{|l|l|l|}
\hline Care partners & Caregiver & \\
\hline Thesaurus & Same as CINAHL & \\
\hline Text words & Home health care & \\
\hline Home care services & & \\
\hline Emtree & & \\
\hline Text words & Same as CINAHL & \\
\hline
\end{tabular}

This article is protected by copyright. All rights reserved. 


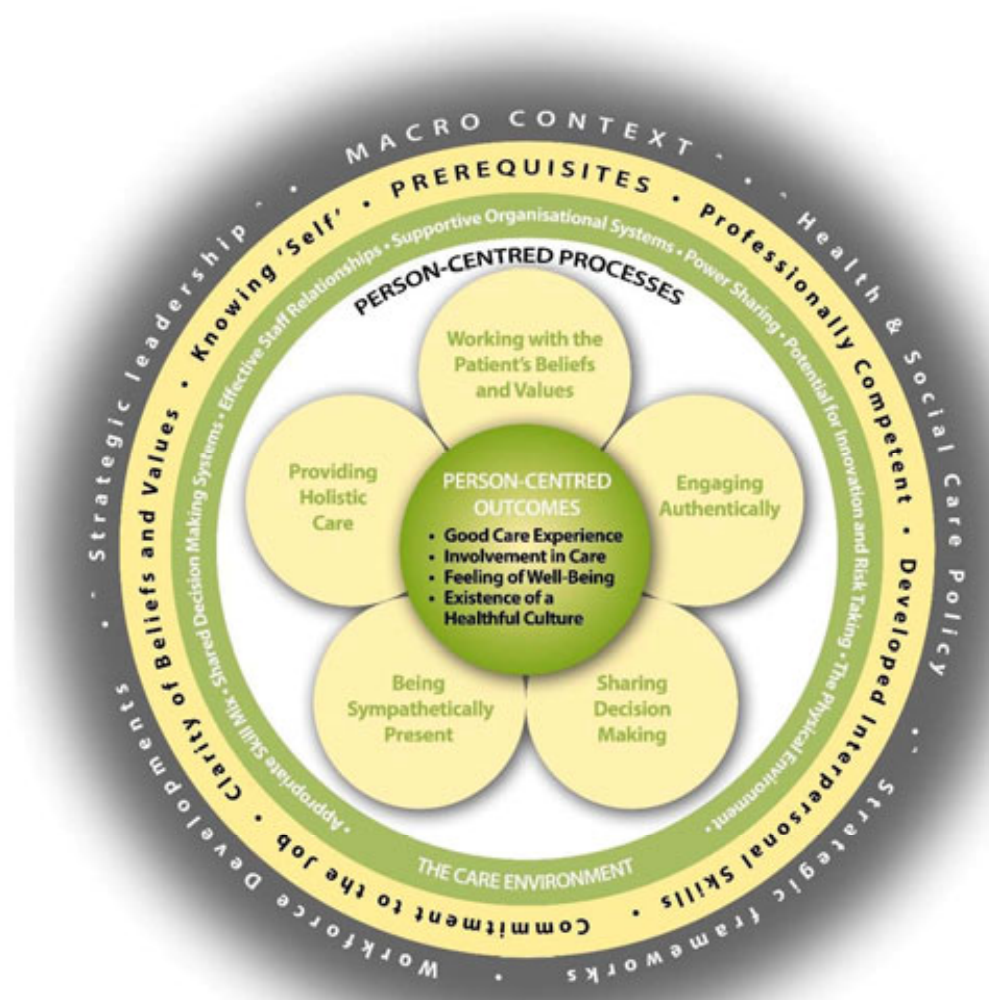

This article is protected by copyright. All rights reserved. 


\section{Figure 2. PRISMA 2009 Flow Diagram of selection process}

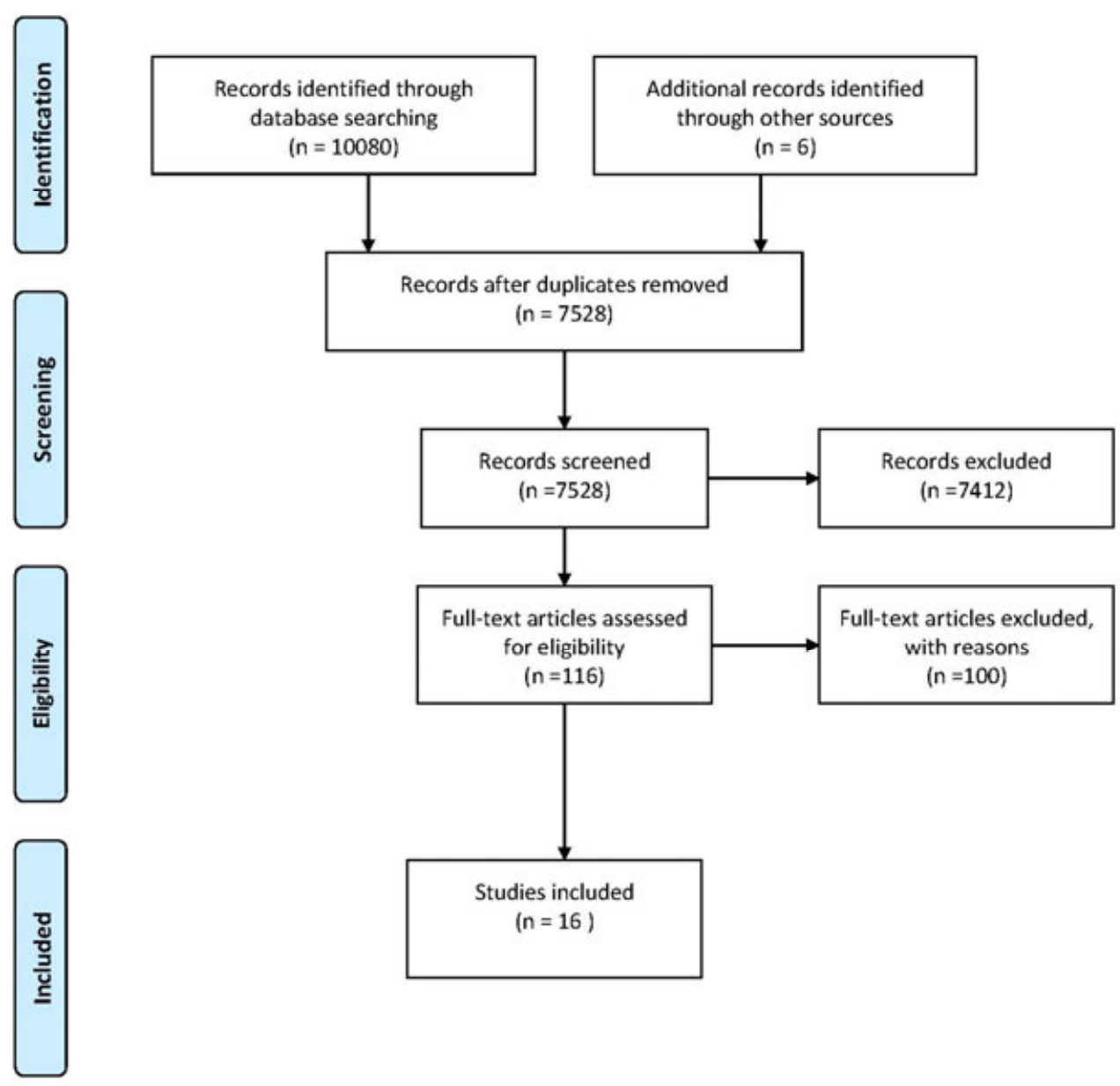

Moher et al. (2009)

This article is protected by copyright. All rights reserved. 